JAN

JAN 41963

INFORMAL AEC RESEARCH AND DEVELOPMENT REPORT

MAY 1962

\title{
ECONOMIC EVALUATION OF CONTROL ROD MATERIALS AND FABRICATION PROCESSES
}

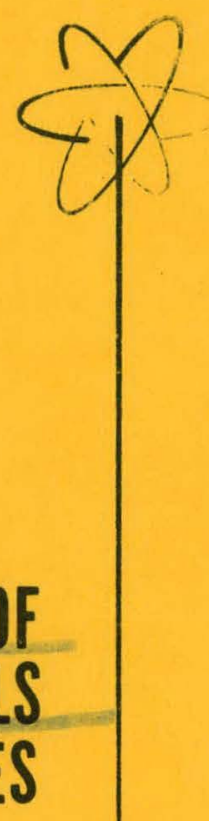

Facsimile Price \$

Microfilm Price \$

Available from the

Office of Technical Services

Department of Commerce

H.E. WILLIAMSON

Washington 25, D. C.

F.H. MEGERTH

U.S. ATOMIC ENERGY COMMISSION

CONTRACT AT(04-3)- 189

PROJECT AGREEMENT NUMBER 4 


\section{DISCLAIMER}

This report was prepared as an account of work sponsored by an agency of the United States Government. Neither the United States Government nor any agency Thereof, nor any of their employees, makes any warranty, express or implied, or assumes any legal liability or responsibility for the accuracy, completeness, or usefulness of any information, apparatus, product, or process disclosed, or represents that its use would not infringe privately owned rights. Reference herein to any specific commercial product, process, or service by trade name, trademark, manufacturer, or otherwise does not necessarily constitute or imply its endorsement, recommendation, or favoring by the United States Government or any agency thereof. The views and opinions of authors expressed herein do not necessarily state or reflect those of the United States Government or any agency thereof. 


\section{DISCLAIMER}

Portions of this document may be illegible in electronic image products. Images are produced from the best available original document. 
GEAP- 4013

INFORMAL AEC RESEARCH

AND DEVELOPMENT REPORT

MAY 1962

ECONOMIC EVALUATION OF CONTROL ROD

MATERIALS AND FABRICATION PROCESSES

By

H. E. Williamson

F. H. Megerth

U.S. Atomic Energy Commission

Contract AT(04-3)-189

Project Agreement No. 4

\section{ATOMIC POWER EQUIPMENT DEPARTMENT \\ GENERAL ELECTRIC}

SAN JOSE, CALIFORNIA

Printed in U.S.A. Available from the Office of Technical Services, Department of Commerce, Washington 25, D. C. 


\section{LEGAL NOTICE}

This report was prepared as an account of Government sponsored work. Neither the United States, nor the Commission, nor any person acting on bebalf of the Commission:

A. Makes any warranty or representation, expressed or implied, with respect to the accuracy, completeness, or usefulness of the information contained in this report, or that the use of any information, apparatus, method, or process disclosed in this report may not infringe privately owned-rights; or

B. Assumes any liabilities with respect to the use of; or for damages resulting from the use of any information, apparatus, method, or process disclosed in this report.

As used in the above, "person acting on bebalf of the Commission" includes any employee or contractor of the Cammission, or employee of such contractor, to the extent that such employee or contractor of the Commission, or employee of such contractor prepares, disseminates, or provides access to, any information pursuant to bis employment or contract with the Commission, or bis employment with such contractor. 


\begin{abstract}
Control rod materials, designs, and fabrication processes are compared for their relative economies. Control rod lifetime data are calculated with a simple approximation of nuclear worth depreciation. These data are used in conjunction with the estimated fabrication costs to determine the cost of using several absorber materials in a typical power reactor on a cost-per-year basis. The effect the control system has on core power density and fuel lifetime is included.
\end{abstract}

\title{
ACKNOWLEDGMENT
}

The authors are indebted to A. J. Alexander for his help in estimating the costs for the various fabrication processes evaluated in this study. 
ECONOMIC EVALUATION OF CONTROL ROD MATERIALS

AND FABRICATION PROCESSES

\section{INTRODUCTION}

The reactor designer is faced with many considerations which he must balance in order to achieve the optimum control rod system. The cost of rod replacement depends not only on the initial cost of the rod but also on the length of time it may operate in the reactor satisfactorily, both from a mechanical and a reactivity standpoint. The economic advantage of a long fuel cycle time usually dictates strong control systems.

It is necessary to consider the allowable reactivity of the individual control rods, and the number of rods required to provide a desired control strength. The total cost of the control rod is not represented simply by the cost of its absorber section, but rather must include the vessel penetration, the drive, and all of the associated equipment. It is usually economically desirable to put as much reactivity into each rod as can be tolerated by safety, material, or coredesign limitations, but is is obviously undesirable to have a situation in which the malfunction of a single control rod could create an uncontrolled portion in the reactor core. In addition, it is desirable to minimize the rod dimensions so as not to occupy a large fraction of the reactor core, or to create large peaks in the thermal flux when the rods are withdrawn. 
The reactor designer needs a simple method which he can use to quickly compare both control rod materials and control rod designs. The results of rigorous methods of analysis are not normally available until the reactor design is well underway, and the design is so far advanced that it does not allow flexibility in the selection of the control rod system. Simple, approximate methods of comparison have been developed so the control rod materials and control rod fabrication processes can be evaluated for design conditions such as lifetime, environment, and control strength. ${ }^{1}$ The objective of these methods is to bring the designers close enough to the optimum system design during the preliminary engineering stages so they can arrive at the best system during the final stages of design.

This report uses these approximate methods, and experimental date on absorber relative worth ${ }^{2}$ and burnup ${ }^{3}$, to compare various combinations of control rod materials and control rod fabrication processes for a typical power reactor. The nuclear lifetime of a given material is a function of the minimum worth required for shutdown of a. cold, clean core, and the amount of excess reactivity to be controlled. These are functions of the reactor system design and cannot readily be generalized. Therefore, the results of this comparison should be considered as indicative of a water-cooled and moderated reactor system only, rather than as a general evaluation of control rod materials for all reactor applications.

Another comprehensive study of control rod economics is that of Anderson, Beck and Theilacker ${ }^{4}$. On the basis of unit fabrication costs 
these authors have made a comparison of several types of rods incorporating different absorber materials by three general fabrication processes. In the present study a number of additional processes are evaluated. The interrelated effects of control system design, core power density, and fuel lifetime have been included in this analysis.

\section{SUMMARY}

Control rod lifetime data calculated with a simple approximation of nuclear worth depreciation are used in conjunction with estimated fabrication costs to determine the costs of using several absorber materials in a typical power reactor ${ }^{5,6}$ on a cost per year basis. The effect the control system has on core power density and fuel lifetime is included. The results are summarized in Figures 1, 2, 3 and 4.

Figure 1 illustrates the calculations based on the assumption that within a maximum life of 20 years the control rod lifetime will be determined by its nuclear worth depreciation rather than loss of mechanical integrity. The control rod types are listed in the order of increas: ing annual costs. The boron carbide-in-tubes and silver-indiumcadmium extruded rods head the list as being the two most economical rod types. There is very little difference between them; the $\mathrm{B}_{4} \mathrm{C}$-intubes rod is listed first because its economics are based on a shorter rod lifetime.

Multiple bars are shown for each control rod type. These bars illustrate the fact that it is economically more attractive to use the 


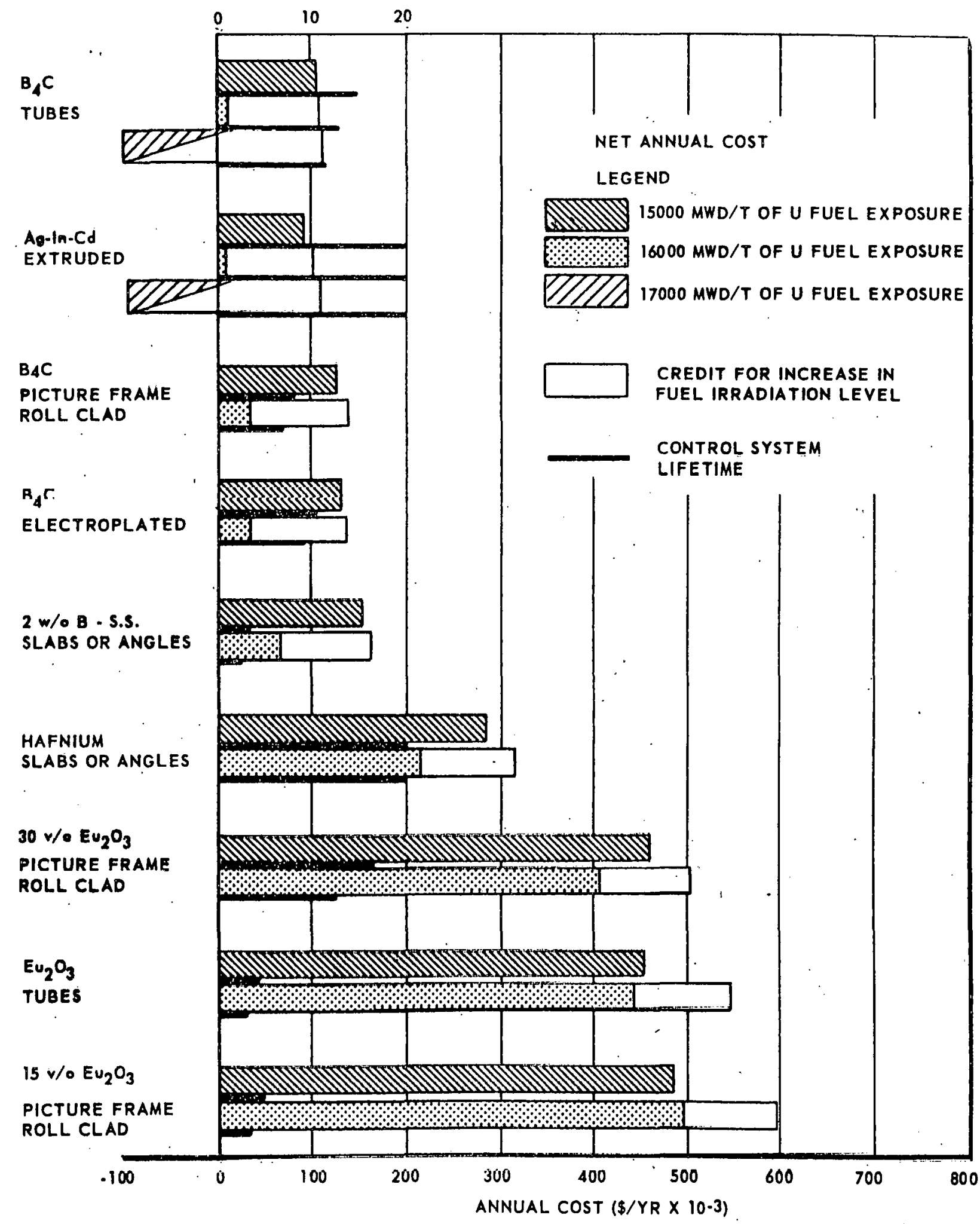

FIGURE I

ANNUAL COSTS OF VARIOUS MAXIMUM LIFETIME CONTROL ROD SYSTEMS FOR DIFFERENT FUEL DISCHARGE IRRADIATION LEVELS 
$B_{4} C$

TUBES

$\mathrm{B}_{4} \mathrm{C}$

ELECTROPLATED

$\mathrm{B}_{4} \mathrm{C}$

PICTURE FRAME ROLL CLAD

Ag-In-Cd

EXTRUDED

HAFNIUM

SLABS OR ANGLES

$30 \mathrm{v} / \circ \mathrm{Eu}_{2} \mathrm{O}_{3}$

PICTURE FRAME

ROLL CLAD

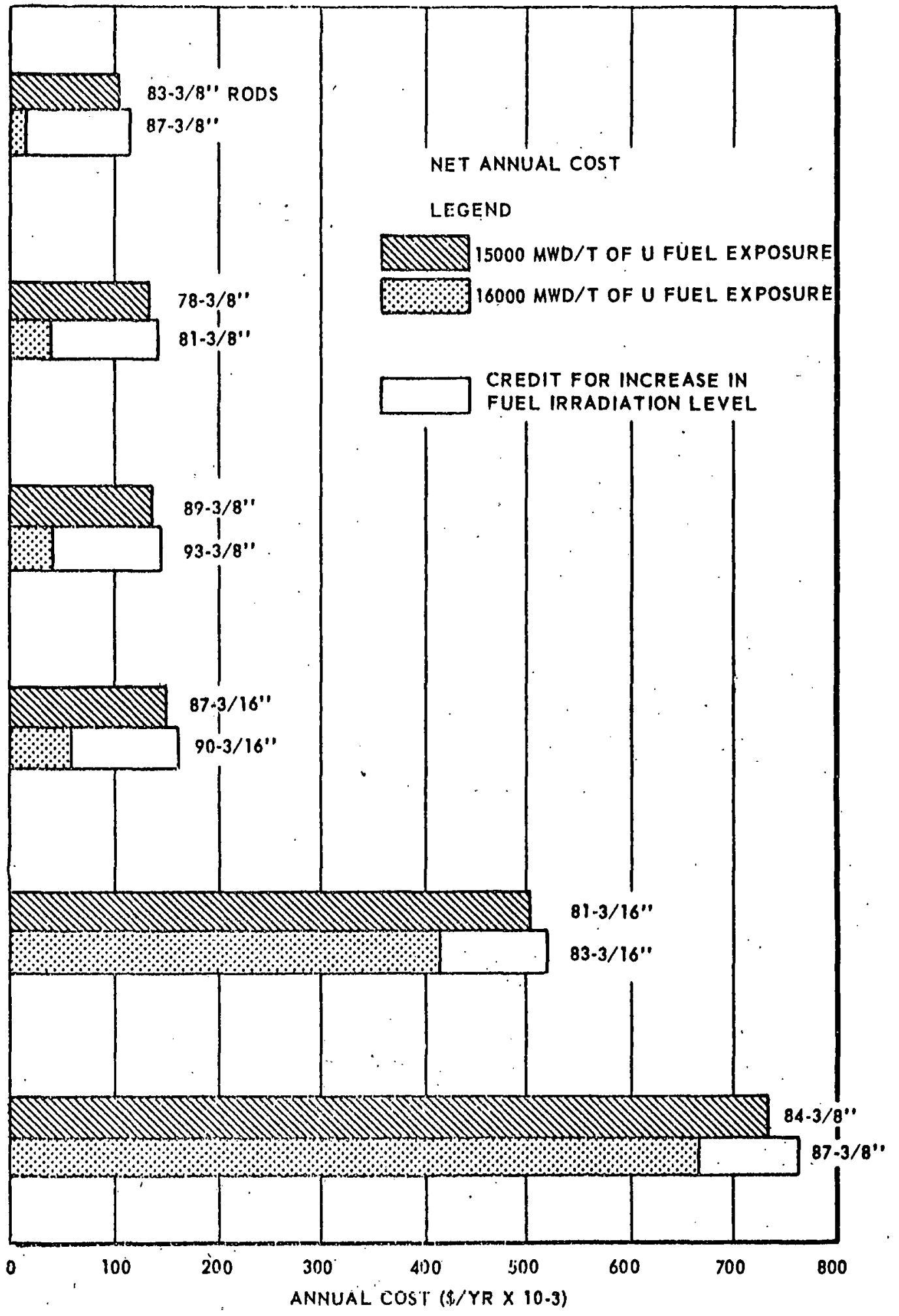

FIGURE 2

ANNUAL COSTS OF VARIOUS 5-YEAR FULL-SIZE-ROD

CONTROL SYSTEMS FOR FUEL DISCHARGE IRRADIATION LEVELS

OF 15,000 MWD/T.U AND $16000 \mathrm{MWD} / \mathrm{T} \cdot \mathrm{U}$ 


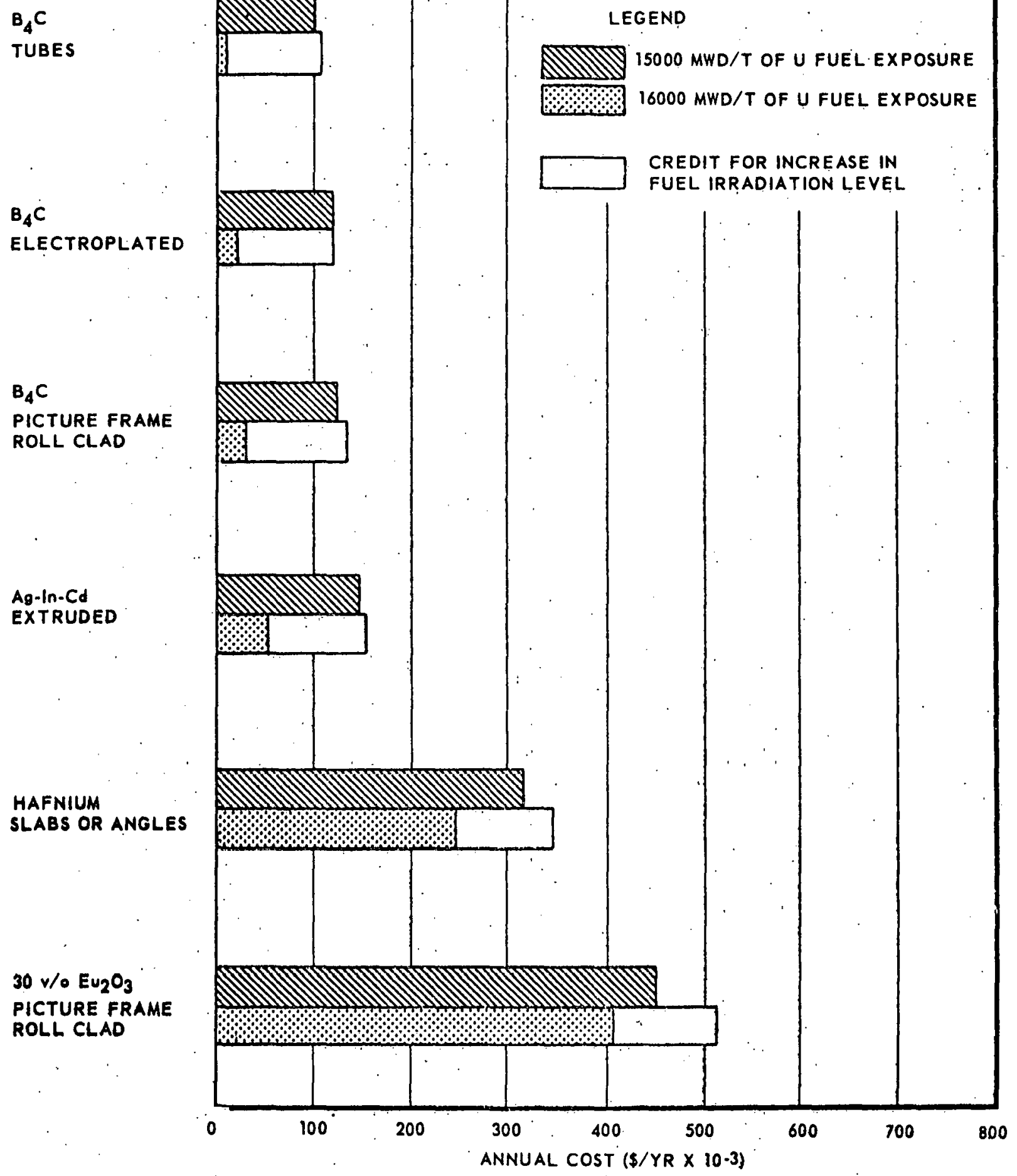

FIGURE 3

ANNUAL COSTS OF VARIOUS 5-YEAR 97-ROD

CONTROL SYSTEMS FOR FUEL DISCHARGE IRRADIATION

LEVELS OF 15,000 MWD/T.U AND 16,000 MWD/T.U

$-6-$ 


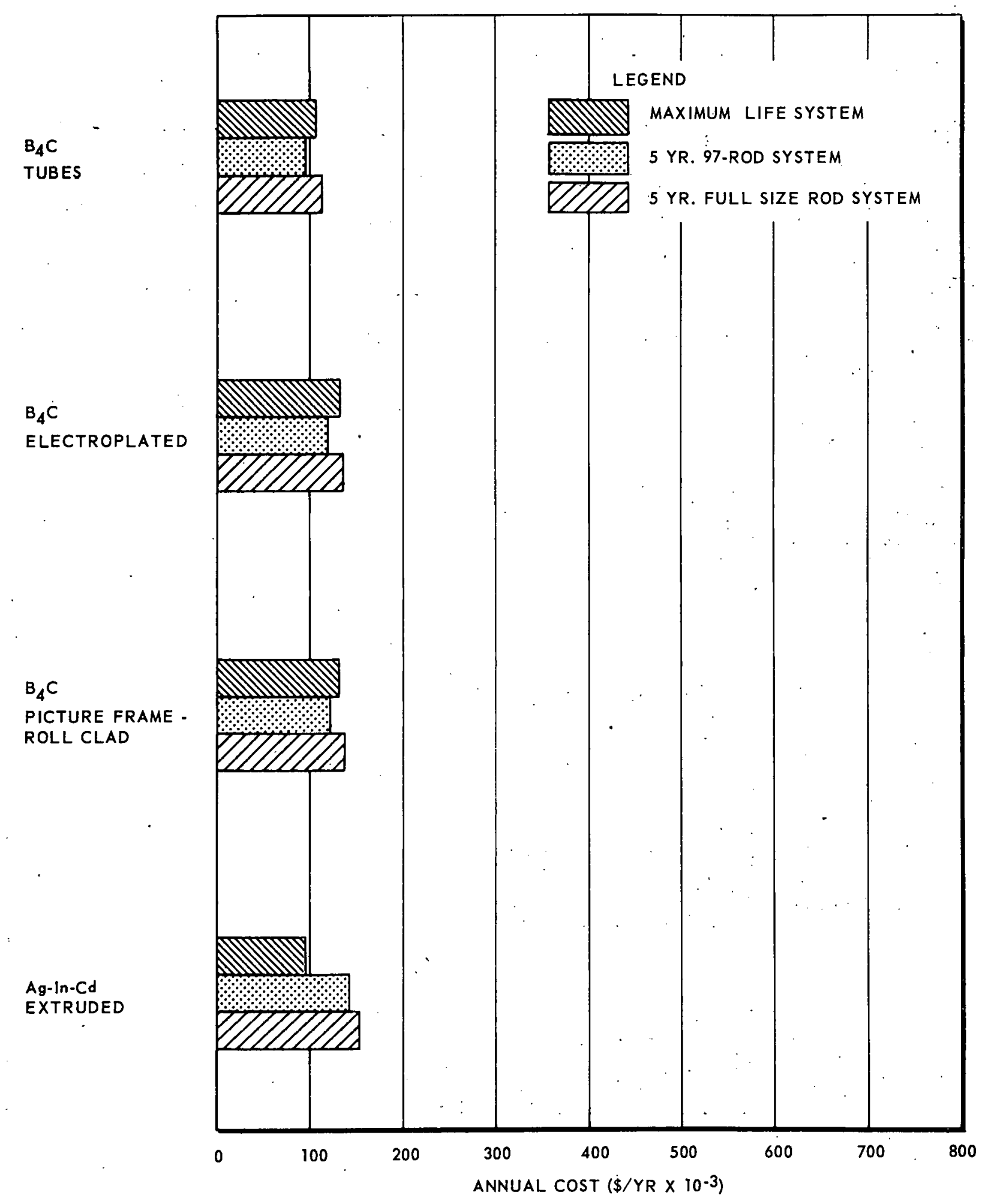

FIGURE 4

ANNUAL COSTS OF SEVERAL CONTROL ROD SYSTEMS FOR FUEL DISCHARGE IRRADIATION LEVEL OF $15,000 \mathrm{MWD} / \mathrm{T} \cdot \mathrm{U}$ 
capacity of the control system to extend fuel exposure at the sacrifice of control rod lifetime. The savings in fuel cycle costs from extended fuel life far exceed the increased costs associated with shorter control rod lifetime.

The control rod may be limited to a lifetime shorter than its nuclear capability by corrosion, wear, or radiation damage that results in dimensional distortion or deleterious effects to the mechanical properties. Since musl of the rods in the list incoporate ideas designed to circumvent the effects of irradiation, but are as yet unproven, the actual lifetime of the rods is uncertain. An alternate method of taking advantage of some of the absorber materials is to reduce the number of rods required to provide the negative reactivity for a five-year control rod lifetime. The results of these calculations are shown in Figure 2. The rod types whose economics are most unfavorably affected, are those that depend on long control rod lifetime for low annual costs.

If the designer is limited in the amount of reactivity he can put in a single rod, but has an absorber material with a high cross-section per unit volume, then he may choose to reduce the thickness of the control blades. Space is left between fuel assemblies to accommodate control rods. Reduction of the amount of space required saves valuable reactor-core volume and reduces neutron peaking in the voids left by the absence of a control rod. The effect of reducing the control rod thickness to provide the negative reactivity for a five-year nuclear 
lifetime is illustrated in Figure 3. In this case, the increase in annual costs is greatest for the silver-indium-cadmium extruded rod.

These comparisons between Figures 1, 2 and 3 are summarized for the four lowest cost rods in Figure 4.

\section{CONCLUSIONS}

The silver-indium-cadmium alloy and boron-carbide exhibit a potential for the lowest control rod costs. The relative costs are so nearly alike that a choice between them would have to be made for each specific application. The attractiveness of the silver alloy is appreciably reduced if its nuclear capability for very long lifetime cannot be achieved because of wear, corrosion, or radiation damage. The economics of the boron carbide rods are affected very. little for the range of lifetimes from 15 down to 5 years.

The relative worth of dysprosia-filled tubes is too low for application in this specific system. In other reactor systems where weaker control rods can be utilized, dysprosia should be considered.

Exotic high cost materials, such as hafnium and europium, are uneconomical despite their long life. Material costs for long-life neutron absorbers should not exceed the $\$ 16 / 1 \mathrm{lb}$ associated with the silver alloy rods if they are to economically compete with the boroncontaining rods. When using europium, the economics of the control 
rod system is nearly as good when the rods are designed for a fiveyear life as when they are designed for a 15-year life. This occurs because the major cost in the control rod system is the cost of europium.

In the range of fuel exposures and control rod lifetimes studied, it is evident that as rods burn down, it is economically more attractive to replace the control rods than it is to reduce the initial reactivity of the core. Obviously, there is a range of fuel exposures and control rod lifetimes where such would no longer be true. The advantage of sacrificing control rod life for extended fuel life is greater for a lowcost control rod than for the high-cost long-life control rods.

Long control rod life is not essential nor necessarily conducive to good economics. Lifetime must be optimized with respect to core design parameters.

\section{DISCUSSION}

\section{A. Eata Requirements}

It is necessary to select an environment and system in which the control rod materials to be evaluated are applied. In order to do this, the AEC Power Reactor studies documented in TID 8500, 8501, 8502 and 8503 were reviewed with respect to control rod information and design characteristics. As a result of this review, it was decided to use the boiling water reactor study reported in TID 8500 as a reference control rod application. The core characteristics of the selected reference are shown in Table $\mathrm{I}^{5}$. 
Some of the reasons for this selection were:

1. A specific system design reduces calculation and provides more complete and consistent information than if a compromise or combination design were selected.

2. Communication with those that have contributed to the bolling water reactor design study was convenient.

3. Conclusions regarding control rod material applications in the bolling water reactor design should be applicable to most light water power reactors.

\section{TABLE I}

\section{REFERENCE APPLICATION}

AEC Boiling Water Reactor Design Study TID 8500

\section{Core Characteristics}

\section{Length}

Circumscribed diameter

Equivalent diameter

Design thermal power

Neutron diffusion length (cold), $\mathrm{L}_{\mathrm{c}}$

$k_{\text {eff }}$, cold, clean $\left(k_{c}\right)$

$\mathrm{k}_{\mathrm{ex}}$, for fuel burnup

$\Delta \mathrm{k}$, shutdown margin

Flux peaking factor
136 inches

133 inches

123 inches

980 megawatts

1.93 centimeters

1. 24

0.060

0.03

4 
TABLE I (Continued)

\section{Control Rod Characteristics}

Number of rods

Size (cross section)

Absorber length
97

$3 / 8$ inch by 8 inches by 8 inches, cruciform

130 inches

The results of this study should not be crtrapolated to systems with other moderators without consideration of the effect the moderator has on relative worth and absorber burnup data.

B. Materials Used

The neutron-absorber materials selected for consideration in this comparative evaluation are: hafnium, boron stainless steel alloy, europium oxide, dysprosium oxide, boron carbide, and silver-indiumcadmium alloy. The estimated costs of these materials to the control rod fabricator are shown in Table II. 
TABLE II

ESTIMATED MATERIAL COSTS

Material

Hafnium strip

2 w/o Natural Boron Stainless Steel Alloy Plate

Europium Oxide

Boron Carbide

Dysprosium Oxide

Ag-In-Cd (80-15-5) Billet

Salts for Nickel Electro-plating Bath

Stainless Steel Powder

Copper Powder

Stainless Steel Strip and Plate (Type 304)

Stainless Steel Tubing (Type 304)
Cost per Pound

$\$ 100.00$

6.35

600.00

10. 00

50.00

16.00

0.30

6.00

1.00

0.50

$\$ 25$ per 100 feet

\section{Fabrication Process}

The fabrication processes used to incorporate the neutronabsorber material in a control rod the size and shape of the reference boiling water reactor control rods are illustrated in Figure 5. Logical combinations of materials and processes are summarized in Table III, together with the estimated fabrication costs per rod. Shop and inspection labor cost, with overhead included, is assumed to be $\$ 11$-perhour for this analysis. In the majority of cases, the unit costs are based upon lots of 97 rods. The exceptions arise through the 
1. SHEET-METAL ANGLES

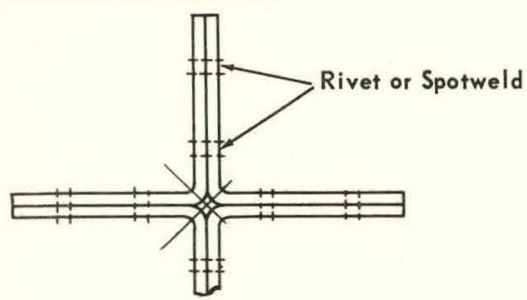

2. WELDED SLABS

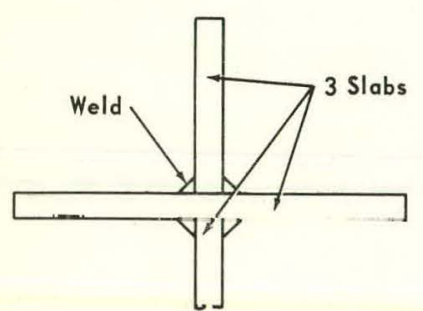

3. ROWS OF TUBES FILLED WITH ABSORBER

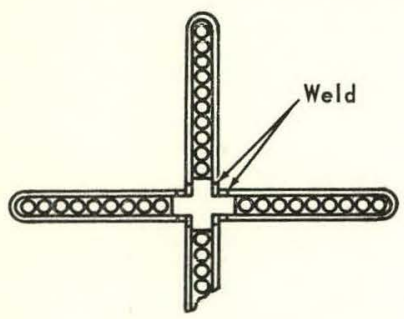

4. PICTURE FRAME - ROLL CLAD DISPERSION
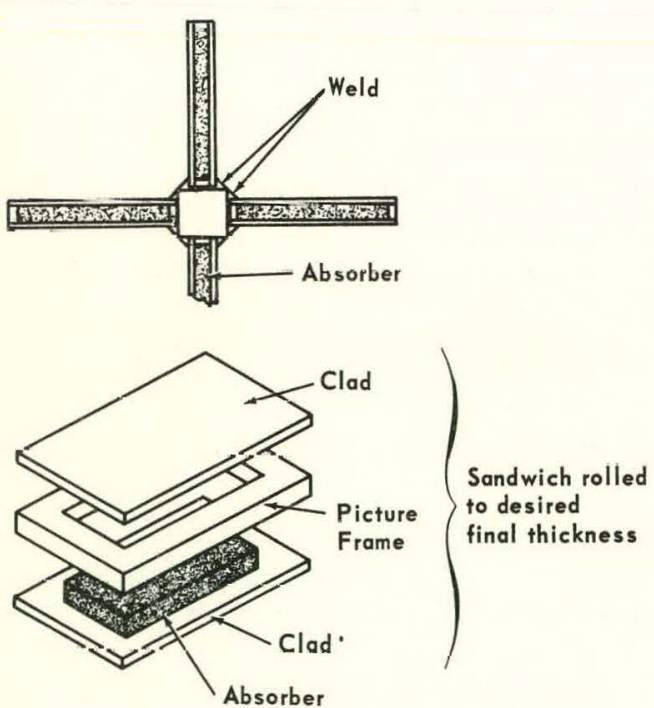
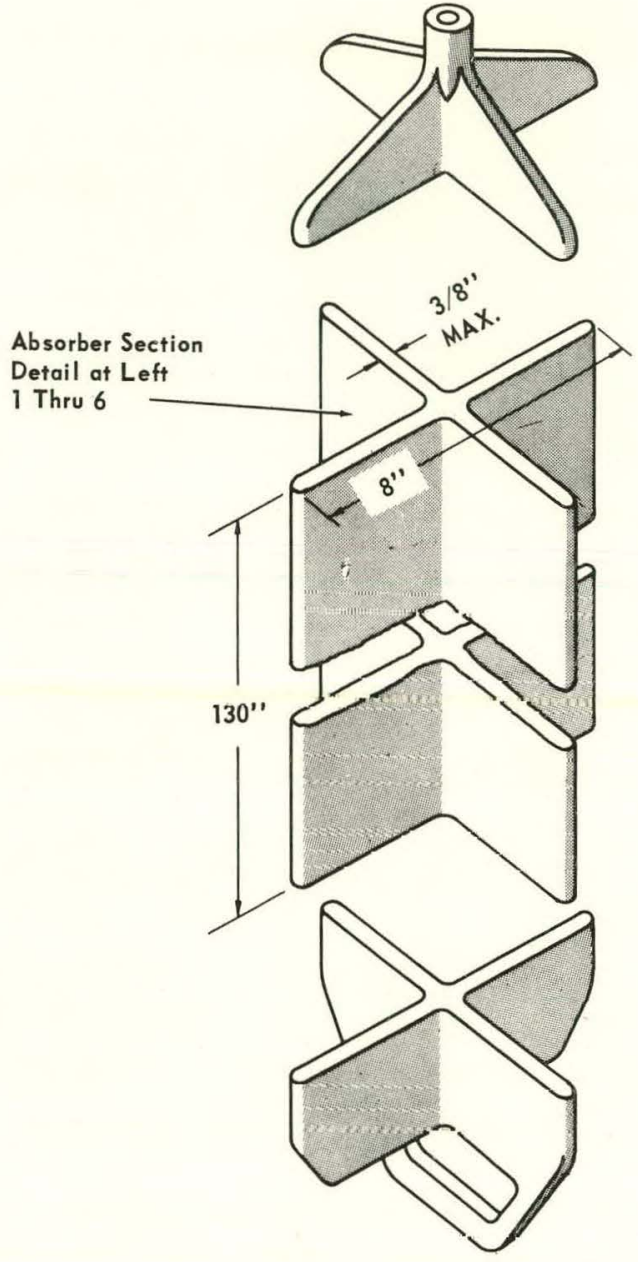

SCHEMATIC DIAGRAMS NOT TO SCALE

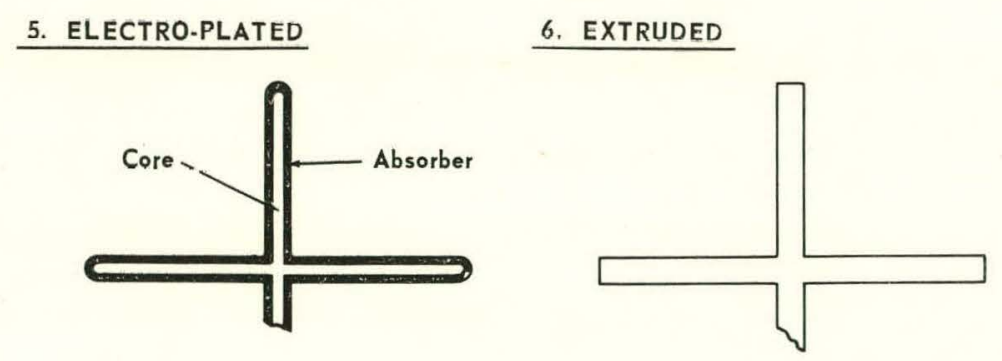

FIGURE 5 
consideration, as a part of this study, of control systems composed of fewer rods designed for five-year lifetimes.

It was assumed that all the fabrication processes have been developed; therefore, no charge is made for development other than the shop development which would be required for the production of a particular shape. It should be noted here that, in fact, while some of the fabrication processes evaluated are well established and furnish considerable data, others have not been reduced to practice but were selected for their apparent practicality or because of their potential for successful development.

The six fabrication processes compared are as follows:

(1) Sheet Metal Angles

The sheet metal angle design was developed for use in the Experimental Boiling Water Reactor (EBWR). 7, 8 , With this type of rod, either hafnium or stainless steel alloy, containing 2 percentby-weight natural boron, is formed in angles of half-blade thickness. A cruciform is fabricated by riveting or spot welding the legs of the angles together at spaced intervals. Two percent is about the limit for boron content in a stainless steel alloy which can be used - without causing excessive brittleness and extreme sensitivity to radiation damage:

(2) Welded Slabs

Either hafnium or two percent natural boron stainless steel is cut into full-width and half-width slabs. Two half-width slabs are 
joined to each full-width slab by intermittent welds along the junctures. Boron stainless steel rods fabricated by this process have been used in the Dresden Nuclear Reactor. ${ }^{9}$

(3) Rows of Tubes

Small diameter stainless steel tubes approximately 130 inches in length are filled with absorber material and sealed by welding end plugs in place. The tubes are stacked in single rows inside "U"-shaper steel sheath sections of 60-mil thiclneas. Four loaded sheaths then are spot-welded to a cruciform-shaped center tie bar. The tubes are filled with one of three absorber materials:

(a) Europium oxide 30 volume/percent in a stainless steel matrix. $\mathrm{Eu}_{2} \mathrm{O}_{3}$ and stainless steel powders are blended and then hot-extruded to form cylinders of the desired diameter. The stainless steel serves to dilute the very expensive europium oxide and protects it from hydration in the event that defects in the cladding tube permit waler lu reach the matrix.

(b) Dyprosium oxide stabilized with 25 weight/percent titanium dioxide. The $\mathrm{Dy}_{2} \mathrm{O}_{3}$ and $\mathrm{Ti}_{2}$ are blended, cold pressed into pellets, and fired at approximately $1500 \mathrm{C}$. The titanium dioxide serves to stabilize the dysprosium oxide against hydration in the event water gets inside the cladding tube ${ }^{10}$.

(c) Boron carbide. The $\mathrm{B}_{4} \mathrm{C}$ powder is sized, loaded in the tubes, and densified by vibratory compaction followed by swaging of the tubes. The $\mathrm{B}_{4} \mathrm{C}$-in-tubes control rod has been applied in several experimental power reactors and the Dresden Nuclear Power Station. 11 
(4) Picture Frame-Roll Clad Dispersion

The absorber material is mixed with a metallic powder stainless steel is used with the rare earth oxides or copper with $\mathrm{B}_{4} \mathrm{C}$. Compacts of the absorber-metal dispersion are produced by cold pressing and sintering. Several of these compacts are set in a stainless steel picture frame, cover plates are welded to each side of the frame, and the interior of the resulting absorber billet is evacuated. An absorber blade is then formed by hot rolling the billet. In the process the cover plates and frames are bonded to the metallic dispersion. The cruciform is made by welding four blades to a center bar. The dispersions contain either 15 or 30 volume/percent europium oxide, 30 volume/percent dysprosium oxide, or 30 volume/percent boron carbide.

The fabrication of this type of rod in cruciform shape has not been reported. However, the Stationary Medium Power Reactor (SM-1), formerly the Army Package Power Reactor (APPR-1), has employed a flux trap, or "square tube", type of control rod made by joining four picture frame-roll clad absorber blades at the edges. The "meat" portion of these blades is a dispersion of $\mathrm{Eu}_{2} \mathrm{O}_{3}$ in elemental stainless steel of type 304 composition. 12 The production of stainless steel clad $\mathrm{B}_{4} \mathrm{C}$-copper dispersions, by a roll-cladding process differing somewhat from that described above, also has been reported. 13 
(5) Electro-plated

A layer of nickel containing a dispersion of small boron carbide particles is electrolytically deposited onto slotted stainless steel base plates. ${ }^{14}$ The $\mathrm{B}_{4} \mathrm{C}$ particles are present as a suspension in the plating bath. A thin, nickel coat is plated on the $\mathrm{B}_{4} \mathrm{C}-\mathrm{Ni}$ dispersion surface in order to seal the surface carbide particles. The deposited dispersion is 30 volume/percent $\mathrm{B}_{4} \mathrm{C}$. It appears that 30 volume/percent boron carbide is about the maximum capacity of the nickel plate. The final cruciform is formed by slipping two plates together and bolting.

An electro-plated $\mathrm{B}_{4} \mathrm{C}$ - $\mathrm{Ni}$ control rod is being tested in the Vallecitos Boiling Water Reactor. ${ }^{15}$ This particular rod was made by joining the absorber plates in the form of a flux trap.

(6) Extruded

A billet of silver-indium-cadmium alloy is extruded in a cruciform shape. The extruded cruciform is machined to the final dimensions, and a thin layer of nickel is electro-plated on the finished surface to provide corrosion resistance to $545 \mathrm{~F}$ water. The electroplated nickel is diffusion-annealed to reduce the porosity of the coating and to provide a more corrosion resistant coating. The weight percentages of each metal in the alloy used are 80 percent $\mathrm{Ag}, 15$ percent In, and 5 percent Cd. Extruded $\mathrm{Ag}-\mathrm{In}-\mathrm{Cd}$ alloy control rods have been in use in the Yankee Atomic Reactor. $16,17,18$. 


\section{CONTROL SYSTEM LIFETIME CALCULATIONS}

A method for the comparative evaluation of control materials, 1 has been developed to compute the approximate nuclear worth and life of various neutron absorber materials. This method uses the relative worth data developed by Becker and Russell, ${ }^{2}$ and the absorber burnup data produced by Carrothers and Russell, ${ }^{3}$ and relates the surface density of the absorber material in a control rod to reactivity worth and lif etime.

1. Relative Worth

All calculations were based on the assumption that the worth of the control systems would never depreciate to less than that required to hold down a cold, clean core with a 3 percent $\Delta k$ shutdown margin. From GEAP-3344, this minimum worth, relative to a thermally black absorber, can be determined by means of the equation

$$
\mathrm{R}=\frac{\mathrm{V}}{\mathrm{AL}_{\mathrm{c}}}\left(\frac{\Delta \mathrm{k}}{\mathrm{k}}\right)_{\mathrm{c}}
$$

where $\mathrm{V}=$ core volume

$A=$ total surface area of all the control elements. A blade of length 1 and absorber width w has a surface area of $2 \mathrm{wl}$.

$\left(\frac{\Delta k}{k}\right)_{c}^{L_{c}}=$ thermal diffusion length in the cold condition
constem effective worth in cold, clean condition 
Figure 6 shows worth, relative to a 0.020 -inch cadmium slab (a thermally black absorber), as a function of absorber surface density for various control materials. ${ }^{2}$

These curves are based upon bare samples of the materials, but for some designs and materials, cladding is required for corrosion protection, or sheaths may be necessary for structural requirements. These factors affect the relationship between surface density and relative worth. Cladding or sheaths depreciate worth by reflecting or scattering neutrons from the absorber materials, and if the absorber is contained in rows of tubes, part of the neutrons incident upon a control rod blade are transmitted between the absorber columns.

The effect of absorber distribution and of stainless steel cladding or sheathing on the surface density - relative worth relationship was estimated from the results of blackness tests on samples of $\mathrm{B}_{4} \mathrm{C}$-filled tubes carried out in the Vallecitos Atomic Laboratory (VAL) critical assembly facility. Figures 7,8 and 9 show curves for $\mathrm{B}_{4} \mathrm{C}, \mathrm{Dy}_{2} \mathrm{O}_{3}$, and $\mathrm{Eu}_{2} \mathrm{O}_{3}$ incorporated both in the absorber-intubes and roll clad types of control rod. Experimental points A, $\mathrm{B}, \mathrm{C}$, and $\mathrm{C}^{\prime}$ of Figure 7 were obtained from the blackness tests. The curve $\mathrm{C}-\mathrm{C}^{\prime}$ indicates that the relative worth as a function of surface density for $\mathrm{B}_{4} \mathrm{C}$-filled tube arrays and boron slabs have approximately the same curvature. Curves for $\mathrm{B}_{4} \mathrm{C}$ in rows of tubes with various wall thicknesses were produced by considering 


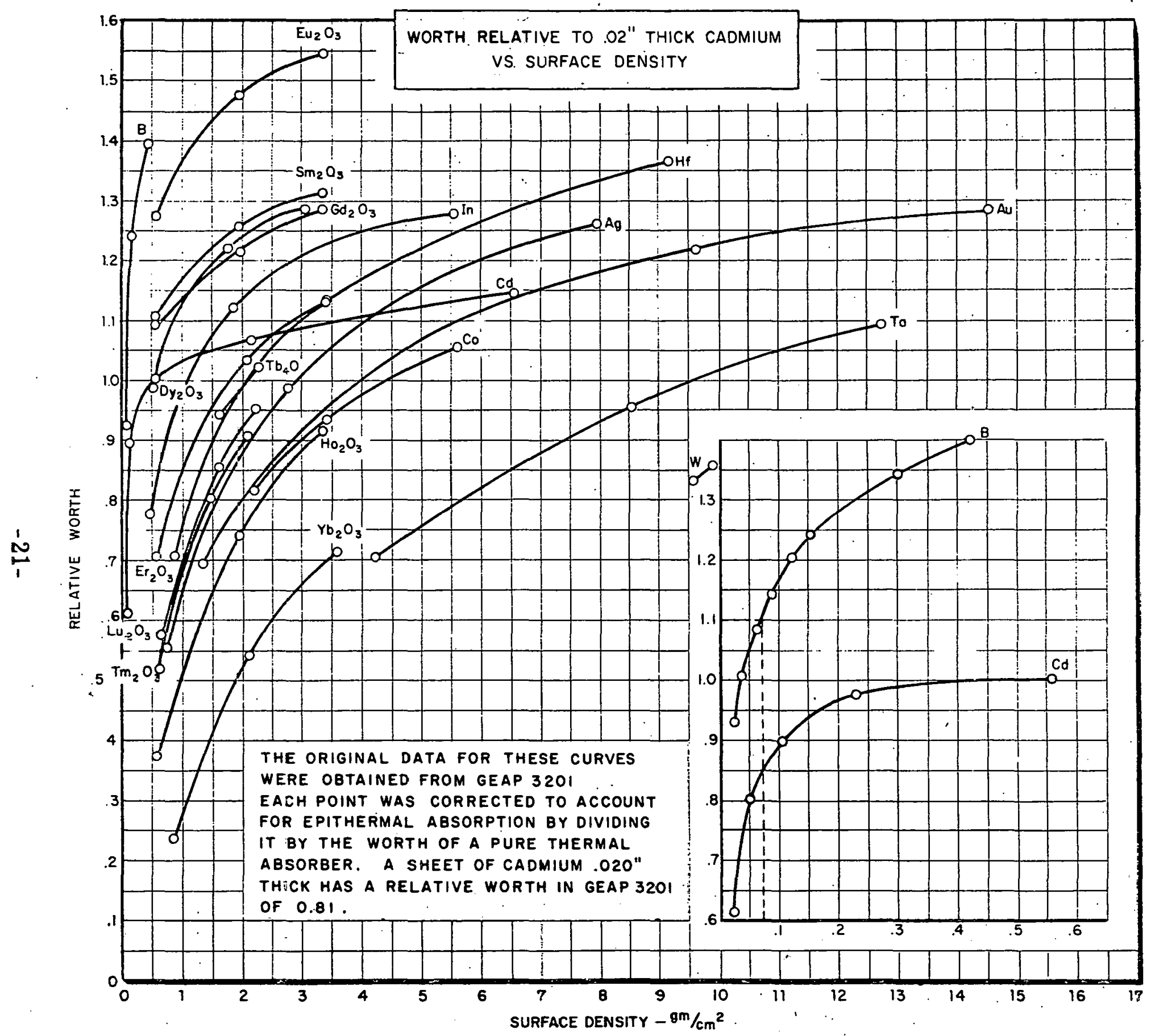

FIGURE 6 


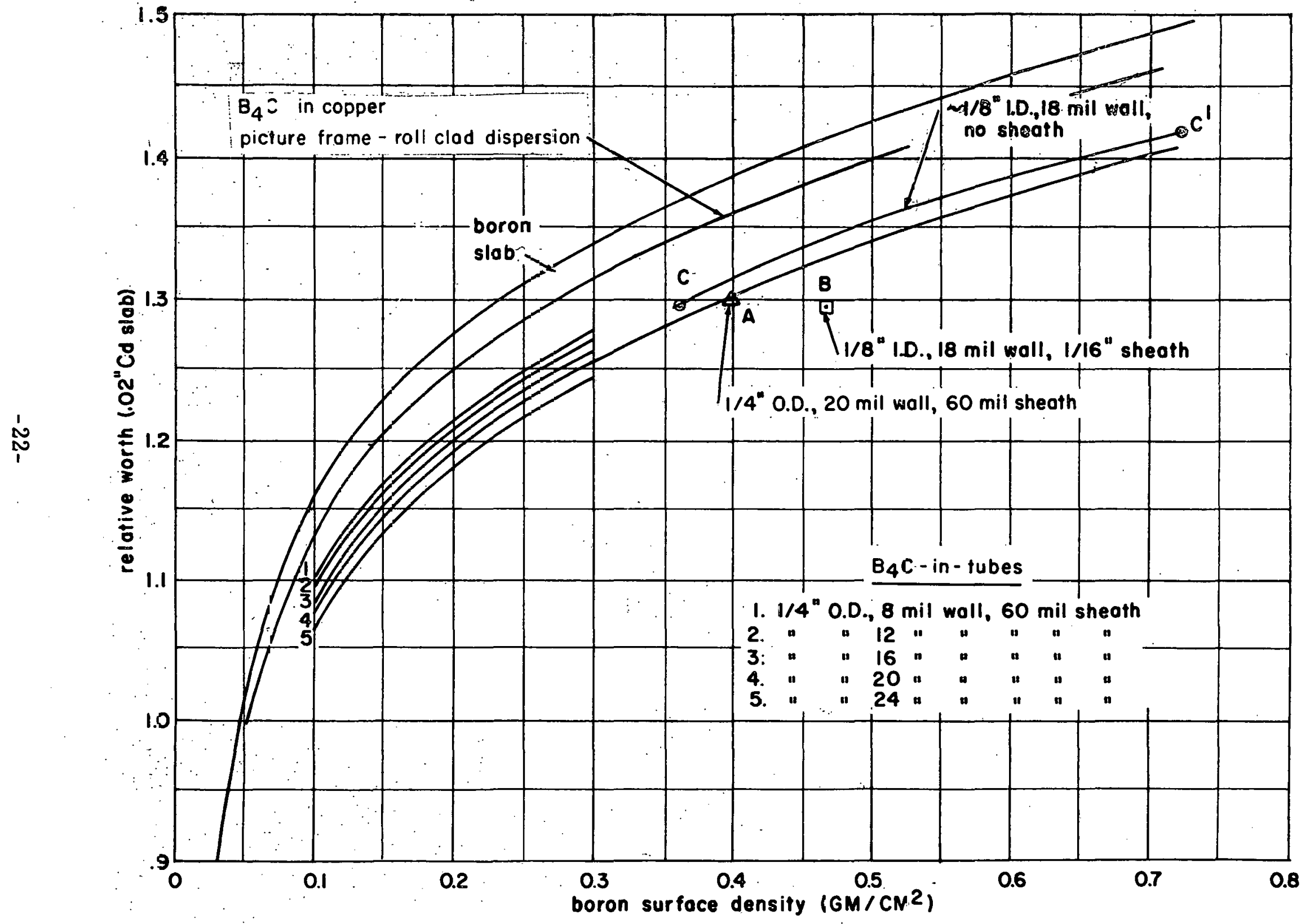

FIGURE - 7 RELATIVE WORTH VS. SURFACE DENSITY FOR $B_{4} C$ 


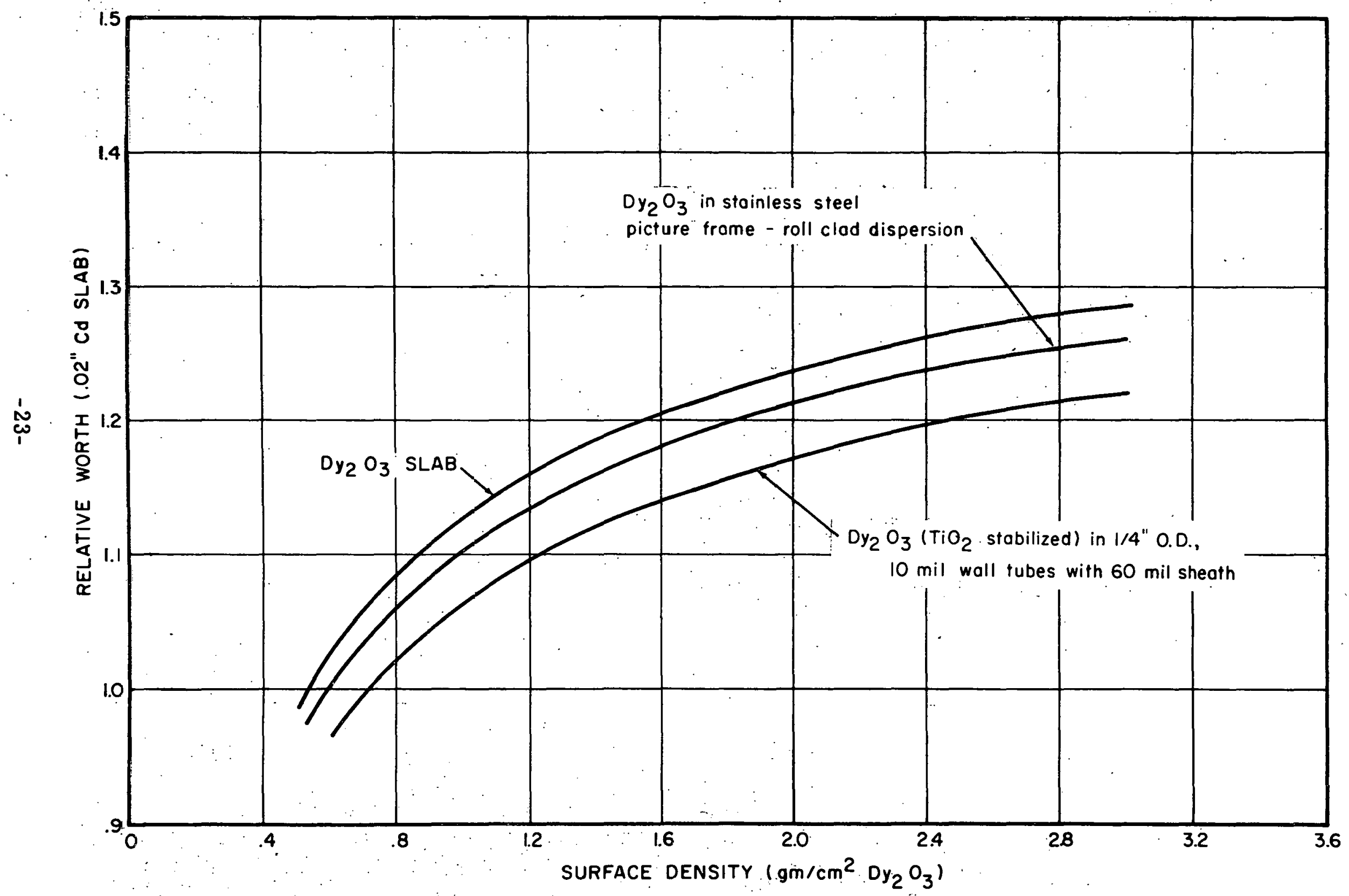

FIGURE 8 - RELATIVE WORTH VS. SURFACE DENSITY FOR Dy $\mathrm{D}_{2} \mathrm{O}_{3}$ 


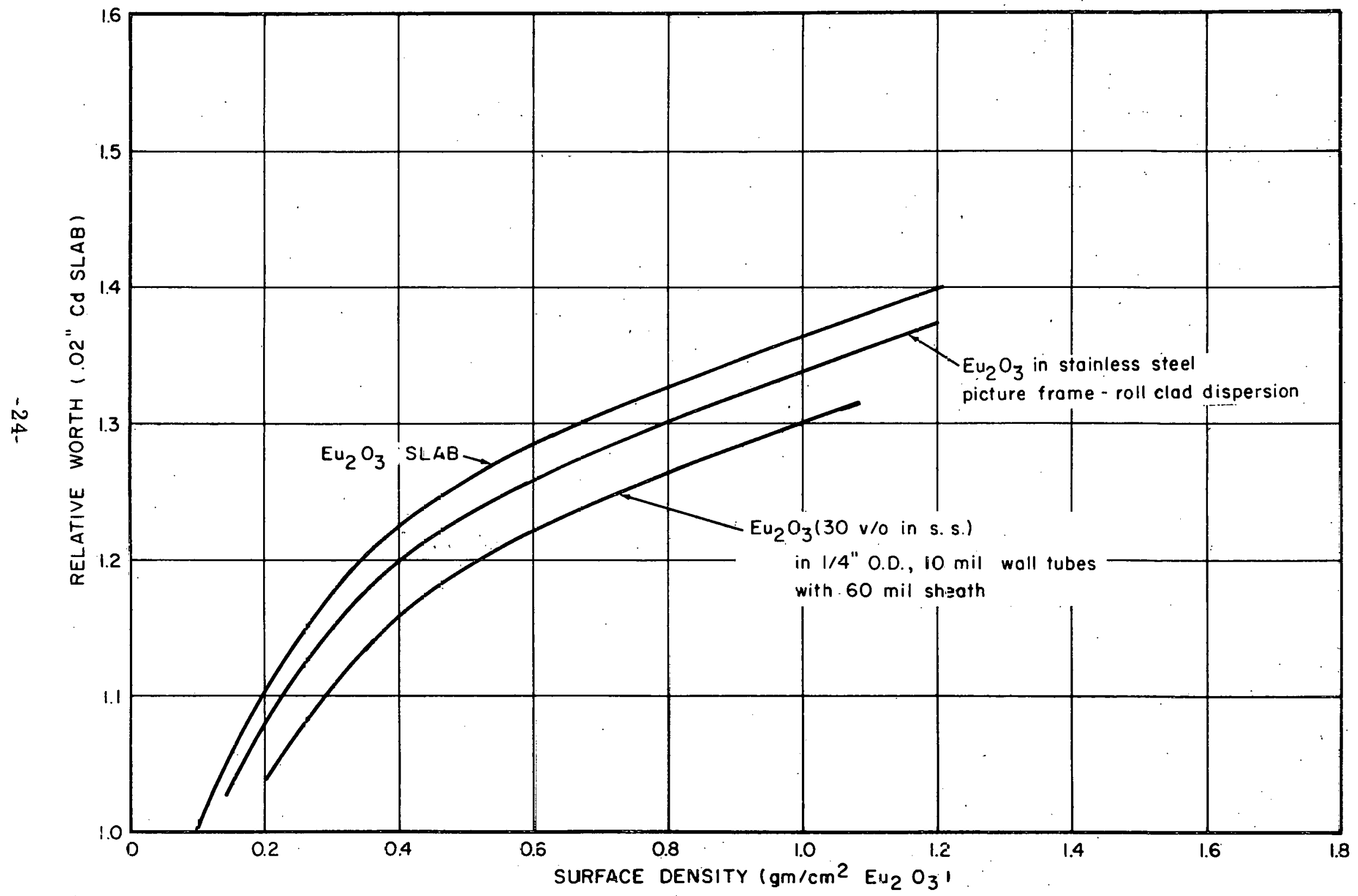

FIGURE 9-RELATIVE WORTH VS. SURFACE DENSITY FOR EU $\mathrm{O}_{3}$ 
the relative cross-sectional areas of $\mathrm{B}_{4} \mathrm{C}$ and stainless steel tube metal as indicated by points $A$ and $B$. The effect of a 60 -mil sheath is illustrated by point $B$ and the curve $C-C^{\prime}$. In producing the curves of Figures 8 and 9 , it was assumed that the tubing and sheath would cause the same decrease in worth for $\mathrm{Dy}_{2} \mathrm{O}_{3}$ and $\mathrm{Eu}_{2} \mathrm{O}_{3}$ as for $\mathrm{B}_{4} \mathrm{C}$. Analysis of blackness tests carried out on $\mathrm{B}_{4} \mathrm{C}$ and $\mathrm{Dy}_{2} \mathrm{O}_{3}$, in stainless steel tubes of identical size and arrangement, indicated that the lowering of the relative worth-surface density curves, due to the tubing, was approximately the same for both absorber materials. 19

In the case of the picture frame-roll clad rods, the final cover plate thickness is 0.0375 -inch. In producing relative worth curves for these rods, the plates were treated in the same manner as were the sheaths, with the assumption that the decrease in worth is proportional to the thickness of the steel cover.

2. Absorber Burn-up

It was assumed that the nuclear life of a control system is expended when the effective absorber surface density, in the area of peak burnup, has been reduced by neutron absorption to a value corresponding to the minimum relative worth. This lifetime was calculated with the equation 1

$$
L=\frac{W N_{O} \cdot\left(\frac{n}{N}\right)_{p}^{f i n}}{M \alpha\left(\frac{\Delta k}{k_{\text {eff }}}\right)_{h} \text { m PC }}
$$


where $L=$ life in years

$\mathrm{W}=$ weight of original absorber in grams

$\mathrm{N}_{\mathrm{O}}=\underset{\text { gram-mole }}{\text { Avogadro's number; } 6.023 \times 10^{23} \text { molecules per }}$

$\left(\frac{n}{N}\right)_{p}^{\text {fin }=\begin{array}{l}\text { peak fractional burnup at end of life- the total number } \\ \text { of neutrons absorbed divided by the total number of } \\ \text { absorber atoms present initially in a given area of } \\ \text { peak neutron flux. }\end{array}}$

$\mathrm{M}$ = atomic weight of absorber

$\alpha=$ number of neulleuss prüluced per kilowatt/yeas: 2: $45 \times 10^{21}$

$\left(\Delta \mathrm{k}_{\mathrm{ex}}\right)_{\mathrm{h}}=$ hot excess reactivity to be controlled by rods

$\left(k_{\text {eff }}\right)_{h}=$ effective reactivity at operating conditions

$\dot{m}=$ hot spot factor for flux peaking on rods

$\mathbf{P}=$ total thermal reactor power in $\mathrm{kw}$

C = load factor

Figures 10 and 11 show, for various elements, the relationship between fractional burnup and the effective fractional surface density; defined as the ratio of absorber surface density at time, $t$, to the initial density.

The ratio of minimum operable surface density to initial surface density then corresponds to the peak fractional burnup of the absorbing element at the end of control system life. The curves of Figures 10 and 11 were determined by calculation, and have been verified by experiment. ${ }^{3}$ 


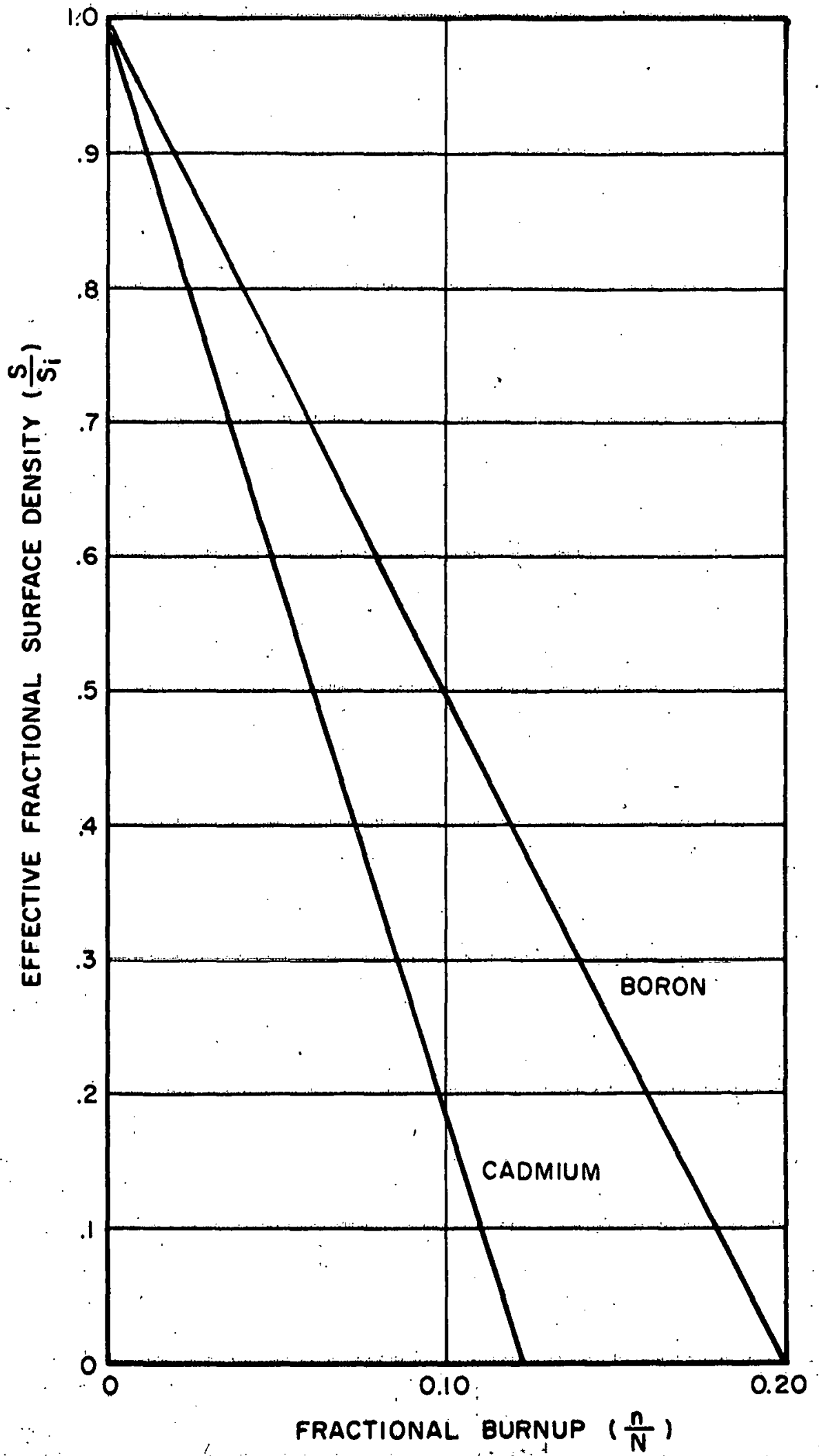

FIGURE 10 EFFECTIVE FRACTIONAL SURFACE DENSITY VS. FRACTIONAL BURNUP (CADMIUM AND BORON ) 


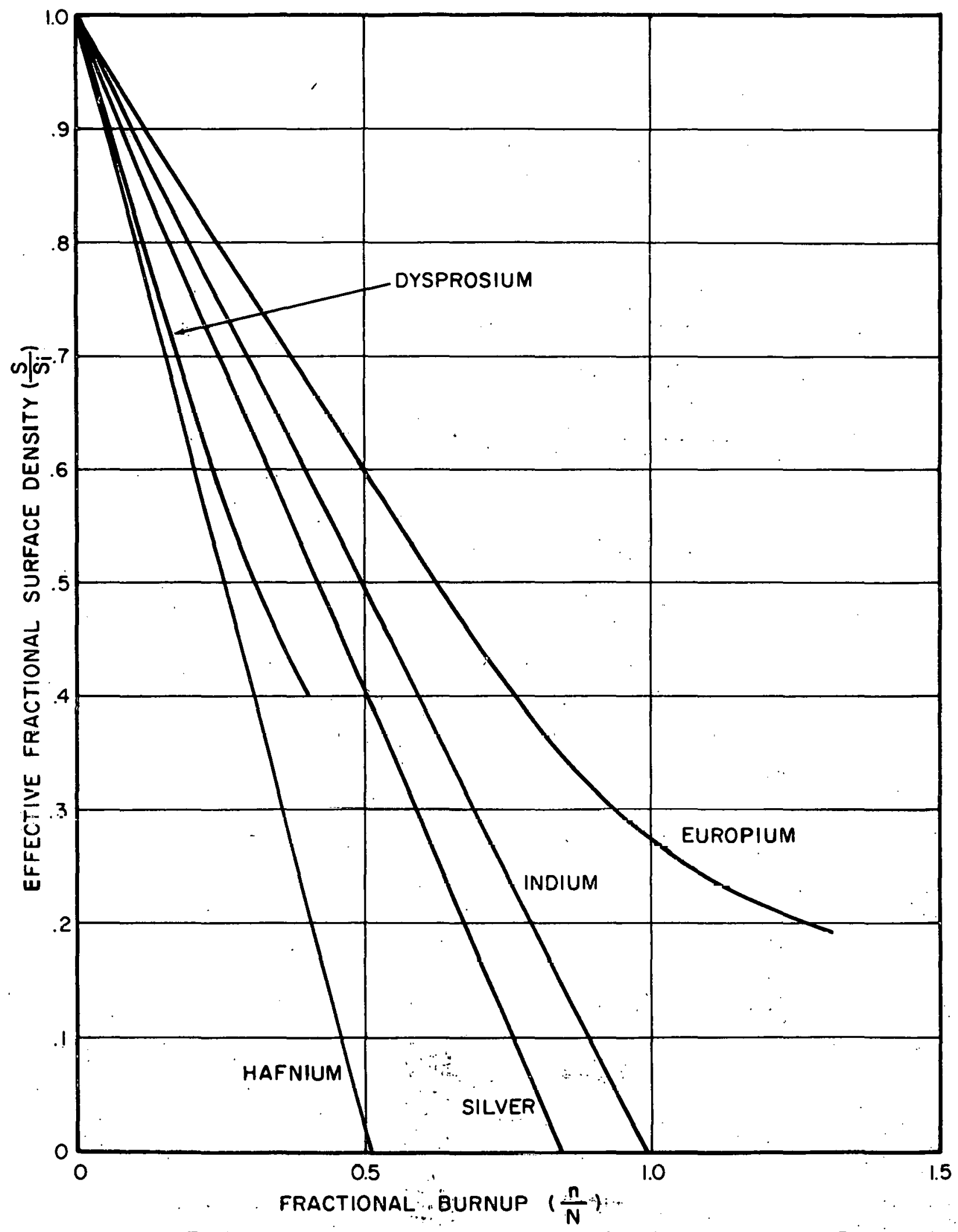

FIGURE II-EFFECTIVE FRACTIONAL SURFACE DENSITY VS. FRACTIONAL BURNUP. (HAFNIÜM; DYSPROSIUM, SILVER, INDIUM; AND EUROPIUM) 


\section{Other Lifetime Limits}

The various absorber materials and fabrication processes were evaluated in this study by applying them to three different types of control systems: 1) maximum nuclear life system, 2) five year system with reduced number of full-size rods, and 3 ) five year system with 97 rods of reduced blade thickness.

Table I shows that the reference control system consists of 97 cruciform rods, $3 / 8$ inch by 8 inches by 130 inches. The maximum nuclear lifetimes of the different combinations of absorbers and fabrication processes were calculated for comparison in this basic reference system design.

However, a control rod may be limited to a life shorter than its nuclear capability by radiation damage that results in dimensional distortion or deleterious effects to the mechanical properties. Most of the rods in this study incorporate ideas designed to circumvent the effects of irradiation. A case in point is the $\mathrm{B}_{4} \mathrm{C}$-in-tubes rod, in which pressure buildup within the tubes caused by helium generation and release had to be taken into account, and the optimum combination of void-volume and tube-strength for accommodation of the gas had to be determined. ${ }^{20}$ Nevertheless, the actual lifetime that each type of rod can attain is not certain.

An alternate method of comparison is to set an arbitrary system lifetime of five years as a basis of control rod design. The designer may choose to reduce the number of rods to the quantity required 
to provide the negative reactivity for this length of nuclear life. A second approach is to design the five-year system by reducing the thickness of the control rod blades. The thinner blades allow a de-crease in the amount of space left between fuel assemblies to accommodate the rods, and valuable core volume can be saved.

\section{E. ANNUAL COST FACTORS STUDIED}

The criterion for economic evaluation of a control rod system is not the first cost of fabricating the rods but the yearly cost of using the rods. For this comparative evaluation, the control rods were considered as depreciating capital equipment, and the rate of depreciation for each control rod type was determined by its lifetime.

The items included in the yearly charge rate are listed in Table IV. The depreciation charge was determined by the sinking fund method with a six percent interest rate.

\section{TABLE N}

\section{Constituents of Yearly Charge Rate.}

Return on Investment

$6.0 \%$

Insurance

1. $0 \%$

Taxes

$$
\text { Total Fixed }=\frac{3.0 \%}{10.0 \%}
$$

Depreciation - a function of the rod life

A reactor life of 30 years was assumed. 
Unit fabrication costs (Table III) are to be regarded as engineering estimates of potential costs and consist only of: (1) shop and inspection labor with overhead, (2) tooling, and (3) materials. General development costs, accounting, marketing, liquidation expenses, and profit are not included.

\section{Value of Extended Fuel Life}

In general, for water-moderated reactors the life of the fuel is extended about $1000 \mathrm{MWD} / \mathrm{T}$ for each percent in excess reactivity available in fresh fuel. This, at the same time, increases the amount of negative reactivity required for shutdown of the cold, clean core and also increases the rate of burnup of the absorber material. Hence, the net value of extended fuel life is the difference between the savings in fuel cycle costs, on a yearly basis, and the associated increase in the annual cost of the control system.

In order to estimate the annual value of increased fuel exposure, all control system' lifetimes and absorber material requirements were calculated for two or more fuel burnup levels. The fuel discharge irradiation level for the reference reactor, given in TID 8500 as 15,000 megawatt days per short ton of uranium, was taken as the basic design level. The amount of credit (V) given to an increase in this level was based upon a fuel fabrication cost of $\$ 1,573,000$ per year ${ }^{5}$ and calculated as

$$
\mathrm{V}=\frac{\mathrm{B}-15,000}{\mathrm{~B}} \times 1.573 \times 10^{6}
$$

where $\mathrm{B}$ is the irradiation level in question. 
2. Economics of Rod Size and Number of Rods in the System

In calculating the costs of rods thinner than the $3 / 8$ inch reference design, credit was given for both the resulting pressure vessel cost savings and the reduction in the cost of fuel inventory. The pressure vessel construction cost savings result from allowable reductions in vessel diameter. These reductions arise from two sources. One is a direct dimensional factor; a decrease in core diameter amounting to the decrcaoc in rod blade thickness times the greatest number of rods in a single row. The second reduction afforded by thinner rods is an indirect one and comes about through the lowering of the flux peaking factor associated with the decrease in gap between fuel assembly channels. The peaking is approximately proportional to the gap width. The lowering of the peaking factor allows the rated thermal power to be obtained from less fuel, and, thus, a core size reduction is possible.

TID 8500 gives the inter-channel gap for the reference core design as $3 / 4$-inch. The local peaking factor for this size gap is taken a.s 1.15. Hence, for a gap of width (g) the peaking factor is:

$$
\mathrm{P}=1+\frac{0.15 \mathrm{~g}}{0.750}
$$

The decrease in fuel inventory is then proportional to $(1-\mathrm{P} / 1.15)$ and the decrease in core and pressure vessel diameters as a result of peaking reduction is proportional to $(1-\mathrm{P} / 1.15)^{1 / 2}$

For the reference reactor the pressure vessel inside diameter is 147.0 inches. It was calculated that by using the thinnest rods 
considered in this study, one could reduce the vessel diameter to 140. 5 inches. It was estimated that within this 6.5 -inches range of diameters the variation in pressure vessel construction cost would amount to $\$ 30,000-$ per-inch-of-change in diameter.

The annual cost of fuel inventory was taken as the sum of the $\mathrm{UO}_{2}$ use charge and the core capitalization. TID 8500 lists the use charge rate for the reference reactor as $\$ 634,000$ per year ${ }^{6}$, and the core capitalization was calculated to be $\$ 308,000$ per year.

Similar credit through core size reduction could not be given to the use of fewer rods than the standard number of 97 . Even in the case of the hafnium rods, in which as few as 71 rods are required for a five-year control system, the total difference in rod crosssectional area is small when compared to the core area. It is doubtful that more than a small fraction of this rod area difference could be applied so as to decrease the core diameter. It is equally doubtful that fewer rods could be arranged so as to significantly reduce the interchannel gap. The economic advantage of using a reduced number of rods is gained solely from the decrease in costs of vessel penetration and of manufacturing and installing the control rods, rod drives, and associated equipment.

\section{F. ANNUAL COSTS FOR VARIOUS CONTROL SYSTEMS}

1. Annual Costs for Maximum Life Control Systems

The maximum control system lifetimes were calculated by applying the various combinations of absorber materials and 
fabrication processes to the basic reference system design. However, the maximum life period was assumed to be limited to no more than 20 years. For cases in which the maximum achieveable surface densities were in excess of those required for this length of life, only the amount of material required to assure a 20-year lifetime was used.

The annual costs for maximum life systems of the various types of control rods are given in Table V. The hafnium and silverindium-cadmium systems were limited to 20 -year lifetimes by reducing the rod blade thicknesses to dimensions less than the 3/8-inch maximum. The credit shown for this reduction in size is the sum of the resulting pressure vessel cost savings and the value of the allowable reduction in fuel inventory, both on an annual basis.

Note, that with rods of relatively low unit fabrication costs and long lifetimes, the base annual system cost is increased less than $\$ 10,000$ per year by a fuel life extension of $1000 \mathrm{MWD} / \mathrm{T}$ beyond the design level of $15,000 \mathrm{MWD} / \mathrm{T}$. The same extension of fuel life may increase the cost of an expensive, short-lived rod by an amount approximately equal to the $\$ 98,000$ per year fuel cycle savings.

As the fuel irradiation level is further extended beyond 15, 000 $M W D / T$, it is possible for the total decrease in annual cost of fuel to exceed the base annual cost of the control system. Thus, when 
the net annual costs for the $\mathrm{B}_{4} \mathrm{C}$-in-tubes and $\mathrm{Ag}-\mathrm{In}$ - $\mathrm{Cd}$ systems were calculated on a basis of 17,000 MWD/T fuel exposure, negative values were obtained. Similar results would be obtained if the calculations for other low cost systems listed in Table $V$ were based on burnups greater than 16,000 MWD/T. However, an optimum fuel irradiation level exists for every control system. Beyond this level the base control system cost will increase at a rate greater than the rate of increase in fuel cycle savings.

Table $\mathrm{V}$ shows the $\mathrm{B}_{4} \mathrm{C}$-in-tubes and $\mathrm{Ag}$ - $\mathrm{In}$ - $\mathrm{Cd}$ rods as the most economical types for application in the maximum lifetime control system. In comparing these systems note that $\mathrm{B}_{4} \mathrm{C}$-in-tubes gains a small economic advantage over $\mathrm{Ag}-\mathrm{In}-\mathrm{Cd}$ as fuel life is increased from $15,000 \mathrm{MWD} / \mathrm{T}$ to $17,000 \mathrm{MWD} / \mathrm{T}$.

2. Annual Costs for Five Year Full-Size-Rod Control Systems

In general, the absorber materials in these systems were incorporated in rods $3 / 8$-inch by 8 inches by 130 inches. The number of rods required for a five-year lifetime was calculated for each case.

The annual costs for several five-year, full-size rod systems are given in Table VI. A comparison of these systems with the maximum life systems in Table $\mathrm{V}$ shows that the annual costs for the types of rods using the relatively low cost boron carbide remain nearly constant as lifetime is decreased from the maximum number of years down to five years. On the other hand, the 
control rods which employ expensive absorber materials are definitely more costly in five-year, full-size rod systems than in maximum life systems.

Systems of $3 / 16$-inch hafnium and silver-indium-cadmium rods were also included in this portion of the study because they demonstrate the economic advantage which may be gained by decreasing the absorber thickness while increasing the number of rods in the five - ycar system.

3. Annual Costs for Five Year 97-Rod Control Systems

In these systems of 97 rods, the absorber section blade thickness required for a five-year lifetime was calculated for each combination of material and fabrication process.

The annual costs for several five-year, 97-rod systems are given in Table VII. The pressure vessel cost savings and the value of the reduction in fuel inventory which accompany the use of rods thinner than the 3/8-inch reference design, have been taken into account in the final costs. A comparison of Tables VI and VII shows that when a five-year lifetime is desired, a system of 97 "thin" rods is less costly than a system of full-size rods, regardless. of the absorber or fabrication process employed.

The $\mathrm{B}_{4} \mathrm{C}$-in-tubes rod is the most economical type in the list. The cost of using $\mathrm{B}_{4} \mathrm{C}$-in-tubes in this five-year system is even slightly lower than the cost of using it in a maximum lifetime control system. 


\section{Miscellaneous Charges}

It should be noted that this comparison does not consider some of the advantages of long control rod life. Other expensive equipment associated with the rods, such as control rod followers, will often be replaced with the absorber sections. If this is the case, these costs should be taken into consideration. Including these factors.will particularly affect the low cost; short life systems.

The computation of a yearly cost is not complete without considering some sort of penalty charge for the labor and loss of reactor operating time incurred each time the reactor is shut down to put in new control rods. Only part of the total shutdown charge would be added to the cost of the control rod system because maintenance, fuel reloading, and other operations will also be performed when the reactor is shut down. Both the difficulty of estimating the cost of control rod replacement and the value of reactor downtime, as well as the expectation that rod replacement would be scheduled to coincide with fuel reloading, led to the exclusion of these charges from the comparative costs presented in this report. 


\section{TABLE III}

\section{FABRICATION COSTS PER CONTROL ROD}

\begin{tabular}{|c|c|c|c|c|c|c|c|}
\hline $\begin{array}{l}\text { Fabr:cation } \\
\text { Method }\end{array}$ & Absorber & & Materials & Labor & & oling & Total \\
\hline Riveted or & 2 w $/$ o B-SS & & $\$ 1,550$ & $\$ 580$ & $\$$ & 60 & $\$ 2,190$ \\
\hline Welded Angles & Hafnium & & & & & & \\
\hline & a. 0.093 & inch & 10,400 & 580 & & 60 & 11,000 \\
\hline & b. 0.104 & inch & 11,500 & 580 & & 60 & 12,100 \\
\hline & c. 0.181 & inch & 19,800 & 580 & & 60 & 20,400 \\
\hline & d. 0.187 & inch & 20,600 & 580 & & $80^{1}$ & 21,300 \\
\hline & e. 0.198 & inch & 21,600 & 580 & .. & 60 & 22,200 \\
\hline & f. 0.375 & inch & 40,500 & 580 & & $90^{1}$ & 41,200 \\
\hline Welded Slabs & $2 \mathrm{w} ; \mathrm{O}$ B-SS & & 1,550 & 400 & & 40 & 1,990 \\
\hline & Hafrium & & & & & & \\
\hline & a. 0.093 & inch & 10,400 & 400 & & 40 & 10,800 \\
\hline & b. 0.104 & inch & 11,500 & 400 & & 40 & 11,900 \\
\hline & c. 0.181 & inch & 19,800 & 400 & & 40 & 20,200 \\
\hline & d. 0.187 & inch & 20,600 & 400 & & $50^{1}$ & 21,000 \\
\hline & e. 0.198 & inch & 21,600 & 400 & & 40 & 22,000 \\
\hline & f. 0.375 & inch & 40,500 & 400 & & $60^{1}$ & 41,000 \\
\hline
\end{tabular}

1 Based on cantrol system of less than 97 control rods.

2 Costs for this type rod are based on calculated breakdown of mandfacturer's estimate. 
TABLE III (Continued)

Fabrication

\section{Method}

Rows of Tubes

Absorber
$\mathrm{Eu}_{2} \mathrm{O}_{3}(30 \mathrm{v} / \mathrm{o})$ in $\mathrm{SS}$
$\mathrm{B}_{4} \mathrm{C} .(80 \%$ dense $)$
a. 0.230 inch
b. 0.245 inch
c. 0.370 inch
0.370 inch

Picture Frame Roll Clad

Dispersion

$$
\begin{aligned}
& \mathrm{Dy}_{2} \mathrm{O}_{3}(30 \mathrm{v} / \mathrm{o}) \text { in SS } \\
& \mathrm{Eu}_{2} \mathrm{O}_{3}(15 \mathrm{v} / \mathrm{o}) \text { in SS }
\end{aligned}
$$
a. 0.364 inch

b. 0.375 inch $\mathrm{Eu}_{2} \mathrm{O}_{3}(30 \mathrm{v} / \mathrm{o})$ in SS

a. 0.224 inch

b. 0.244 inch

c. 0.375 inch 0. 375 inch

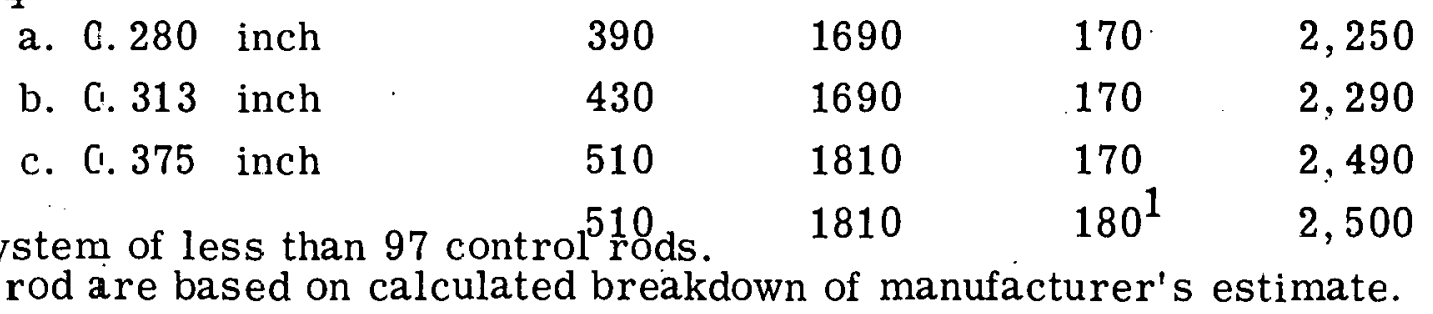

$$
13,100
$$

$1 \grave{6} 40$

$170 \quad 14,900$

$170 \quad 16,700$

$170 \quad 28,400$

$200^{1} \quad 28,400$

\begin{tabular}{|c|c|c|c|c|}
\hline Materials & Labor & \multicolumn{2}{|c|}{ Tooling } & Total \\
\hline$\$ 12,200^{\circ}$ & $\$ 1140$ & $\$$ & 80 & $\$ 13,400$ \\
\hline , & & & & . \\
\hline 620 & 1110 & & 80 & 1,810 \\
\hline 580 & 1060 & & 80 & 1,720 \\
\hline 520 & 890 & & 80 & 1,490 \\
\hline 520 & 890 & & $100^{1}$ & 1,510 \\
\hline
\end{tabular}

26,400

1810

1810

$\begin{array}{rrrr}3,100 & 1810 & 170 & 5,080 \\ 13,400 & 1790 & 170 & 15,400 \\ 13,700 & 1810 & 170 & 15,700\end{array}$

\footnotetext{
${ }_{2}$ Based on control system of less than 97 control rods. 1810
${ }_{\text {Costs for this type rod are based on calculated breakdown of manufacturer's estimate. }}$
} 
TABLE III (Continued)

Fabrication

Method

Electroplated

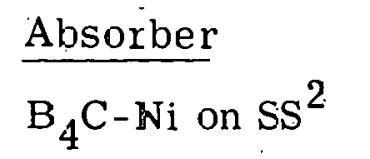

a. 0.255 inch

b. 0.269 inch

c. 0.375 inch

Extruded

í

\begin{tabular}{|c|c|c|c|c|c|}
\hline \multicolumn{2}{|c|}{ Materials } & Labor & \multicolumn{2}{|c|}{ Tooling } & - Total \\
\hline$\$$ & 250 & $\$ 1820$ & $\$$ & 110 & $\$ 2,180$ \\
\hline & 270 & 1820 & & 110 & 2,200 \\
\hline & 370 & 2580 & & 110 & 3,060 \\
\hline & 370 & 2580 & & $140^{1}$ & 3,090 \\
\hline
\end{tabular}

Ag-In-Cd (80-15-5)

$\begin{array}{lllll}\text { a. (1. } 128 \text { inch } & 2860 & 1240 & 220 & 4,320 \\ \text { b. (1. } 141 \text { inch } & 2970 & 1240 & 220 & 4,430 \\ \text { c. (1. } 173 \text { inch } & 3340 & 1240 & 220 & 4,800 \\ \text { d. C. } 1875 \text { inch } & 3540 & 1240 & 250^{1} & 5,030 \\ \text { e. C. } 190 \text { inch } & 3540 & 1240^{\circ} & 220 & 5,000 \\ \text { f. C. } 213 \text { inch } & 3820 & 1240 & 220 & 5,280 \\ \text { g. G. } 375 \text { inc. } & 5750 & 1240 & 270^{1} & 7,260\end{array}$

${ }^{1}$ Based on control system of less than 97 control rods.

${ }^{2}$ Costs for this type rod are based on calculated breakdown of manufacturer's estimate. 
TABLE V

ANNUAL COSTS OF MAXIMUM LIFE CONTROL ROD SYSTEMS

\begin{tabular}{|c|c|c|c|c|c|c|c|c|c|c|}
\hline & $\begin{array}{l}\text { Fabrication } \\
\text { Method }\end{array}$ & $\begin{array}{l}\text { A.bsorber } \\
\text { Material }\end{array}$ & $\begin{array}{c}\text { Fuel } \\
\text { Discharge } \\
\text { Irradiation } \\
\text { Level } \\
\text { (MWD/T-U) } \\
\end{array}$ & $\begin{array}{c}\text { Blade } \\
\text { Thicknes s } \\
\text { (Inch) } \\
\end{array}$ & $\begin{array}{l}\text { Lifetime } \\
\text { (Years) }\end{array}$ & $\begin{array}{c}\text { Fabrication } \\
\text { Cost } \\
\text { Per Rod } \\
\text { (Dollars) } \\
\end{array}$ & $\begin{array}{l}\text { Base Annual } \\
\text { Cost for } \\
\text { Rod System } \\
\text { Including } \\
\text { Rod Drives } \\
\text { (Dollars) } \\
\end{array}$ & $\begin{array}{l}\text { Credit for } \\
\text { Increase } \\
\text { In Fuel } \\
\text { Irradiation } \\
\text { Level Above } \\
\text { 15, 000 MWD } \mathrm{T} \\
\text { (Dollars) } \\
\end{array}$ & $\begin{array}{l}\text { Credit for } \\
\text { Reduction } \\
\text { In Rod } \\
\text { Thickness } \\
\text { (Dollars) } \\
\end{array}$ & $\begin{array}{c}\text { Net } \\
\text { Annual Cost } \\
\text { for Rod } \\
\text { System } \\
\text { (Dollars) } \\
\end{array}$ \\
\hline & \multirow[t]{2}{*}{$\begin{array}{l}\text { Sheet } \\
\text { Metal } \\
\text { Angles }\end{array}$} & Hafnium & $\begin{array}{l}15,000 \\
16,000\end{array}$ & $\begin{array}{l}0.181 \\
0.198\end{array}$ & $\begin{array}{l}20.0 \\
20.0\end{array}$ & $\begin{array}{l}20,400 \\
22,200\end{array}$ & $\begin{array}{l}340,000 \\
361,000\end{array}$ & 98,000 & $\begin{array}{l}46,000 \\
42,000\end{array}$ & $\begin{array}{l}294,000 \\
221,000\end{array}$ \\
\hline & & 2 wio B-SS & $\begin{array}{l}15,000 \\
16,000\end{array}$ & $\begin{array}{l}0.375 \\
0.375\end{array}$ & $\begin{array}{l}3.5 \\
3.0\end{array}$ & $\begin{array}{l}2,190 \\
2,190\end{array}$ & $\begin{array}{l}163,000 \\
175,000\end{array}$ & 98,000 & & $\begin{array}{r}163,000 \\
77,000\end{array}$ \\
\hline & $\begin{array}{l}\text { Welded } \\
\text { Slabs }\end{array}$ & $\begin{array}{l}\text { Hafrium } \\
2 \mathrm{w} / \mathrm{C} \text { B-SS }\end{array}$ & $\begin{array}{l}15,000 \\
16,000 \\
15,000 \\
16,000\end{array}$ & $\begin{array}{l}0.181 \\
0.198 \\
0.375 \\
0.375\end{array}$ & $\begin{array}{r}20.0 \\
20.0 \\
3.5 \\
3.0\end{array}$ & $\begin{array}{r}20,200 \\
22,000 \\
1,990 \\
1,990\end{array}$ & $\begin{array}{l}336,000 \\
359,000 \\
155,000 \\
167,000\end{array}$ & $\begin{array}{l}98,000 \\
98,000\end{array}$ & $\begin{array}{l}46,000 \\
42,000\end{array}$ & $\begin{array}{r}290,000 \\
219,000 \\
155,000 \\
69,000\end{array}$ \\
\hline & $\begin{array}{l}\text { Rows of } \\
\text { Tubes }\end{array}$ & $\begin{array}{l}\mathrm{Dy}_{2} \mathrm{O}_{3}\left(\mathrm{TiO}_{2}\right) \\
\mathrm{Eu}_{2} \mathrm{O}_{3}\left(30 \mathrm{~V}^{2} \%\right) \\
\mathrm{B}_{4} \mathrm{C}\end{array}$ & $\begin{array}{l}15,000 \\
15,000 \\
16,000 \\
15,000 \\
16,000 \\
17,000\end{array}$ & $\begin{array}{l}0.370 \\
0.370 \\
0.370 \\
0.370 \\
0.370 \\
0.370\end{array}$ & $\begin{array}{r}0.5 \\
4.8 \\
3.5 \\
15.0 \\
13.2 \\
11.3\end{array}$ & $\begin{array}{r}-- \\
13,400 \\
13,400 \\
1,490 \\
1,490 \\
1,490\end{array}$ & $\begin{array}{l}458,-000 \\
549,000 \\
107,000 \\
109,000 \\
111,000\end{array}$ & $\begin{array}{r}98,000 \\
98,000 \\
185,000\end{array}$ & & $\begin{array}{r}458,000 \\
451,000 \\
107,000 \\
11,000 \\
-74,000\end{array}$ \\
\hline - & $\begin{array}{l}\text { Picture } \\
\text { Frame } \\
\text { Roll Clad }\end{array}$ & $\begin{array}{l}\mathrm{Dy}_{2} \mathrm{O}_{3} \\
\mathrm{Eu}_{2} \mathrm{C}_{3}(15 \mathrm{v} / \mathrm{o}) \\
\mathrm{Eu}_{2} \mathrm{C}_{3}(30 \mathrm{v} / \mathrm{o}) \\
\mathrm{B}_{4} \mathrm{C}(30 \mathrm{v} / \mathrm{o})\end{array}$ & $\begin{array}{l}15,000 \\
15,000 \\
16,000 \\
15,000 \\
16,000 \\
15,000 \\
16,000\end{array}$ & $\begin{array}{l}0.375 \\
0.375 \\
0.375 \\
0.375 \\
0.375 \\
0.375 \\
0.375\end{array}$ & $\begin{array}{r}0.9 \\
5.4 \\
3.9 \\
16.7 \\
12.9 \\
9.0 \\
7.4\end{array}$ & $\begin{array}{r}5,080 \\
15,700 \\
15,700 \\
28,400 \\
28,400 \\
2,490 \\
2,490\end{array}$ & $\begin{array}{l}680,000 \\
485,000 \\
599,000 \\
462,000 \\
508,000 \\
132,000 \\
138,000\end{array}$ & $\begin{array}{l}98,000 \\
98,000 \\
98,000\end{array}$ & & $\begin{array}{r}680,000 \\
485,000 \\
501,000 \\
462,000 \\
410,000 \\
137,000 \\
40,000\end{array}$ \\
\hline & $\begin{array}{l}\text { Electro- } \\
\text { plated }\end{array}$ & $\mathrm{B}_{4} \mathrm{C}-\mathrm{Ni}$ & $\begin{array}{l}15,000 \\
16,000\end{array}$ & $\begin{array}{l}0.375 \\
0.375\end{array}$ & $\begin{array}{r}10.8 \\
9.7\end{array}$ & $\begin{array}{l}3,060 \\
3,060\end{array}$ & $\begin{array}{l}137,000 \\
140,000\end{array}$ & 98,000 & & $\begin{array}{r}137,000 \\
42,000\end{array}$ \\
\hline & Extruded & $A g-I n-C d$ & $\begin{array}{l}15,000 \\
16,000 \\
17,000\end{array}$ & $\begin{array}{l}0.173 \\
0.190 \\
0.213\end{array}$ & $\begin{array}{l}20.0 \\
20.0 \\
20.0\end{array}$ & $\begin{array}{l}4,800 \\
5,000 \\
5,280\end{array}$ & $\begin{array}{l}146,000 \\
149,000 \\
152,000\end{array}$ & $\begin{array}{r}98,000 \\
185,000\end{array}$ & $\begin{array}{l}48,000 \\
43,000 \\
.39,000\end{array}$ & $\begin{array}{r}98,000 \\
8,000 \\
-72,000\end{array}$ \\
\hline
\end{tabular}


TABLE VI

ANHUAL COSTS OF FIVE-YEAR FULL-SIZE-ROD CONTROL SYSTEME

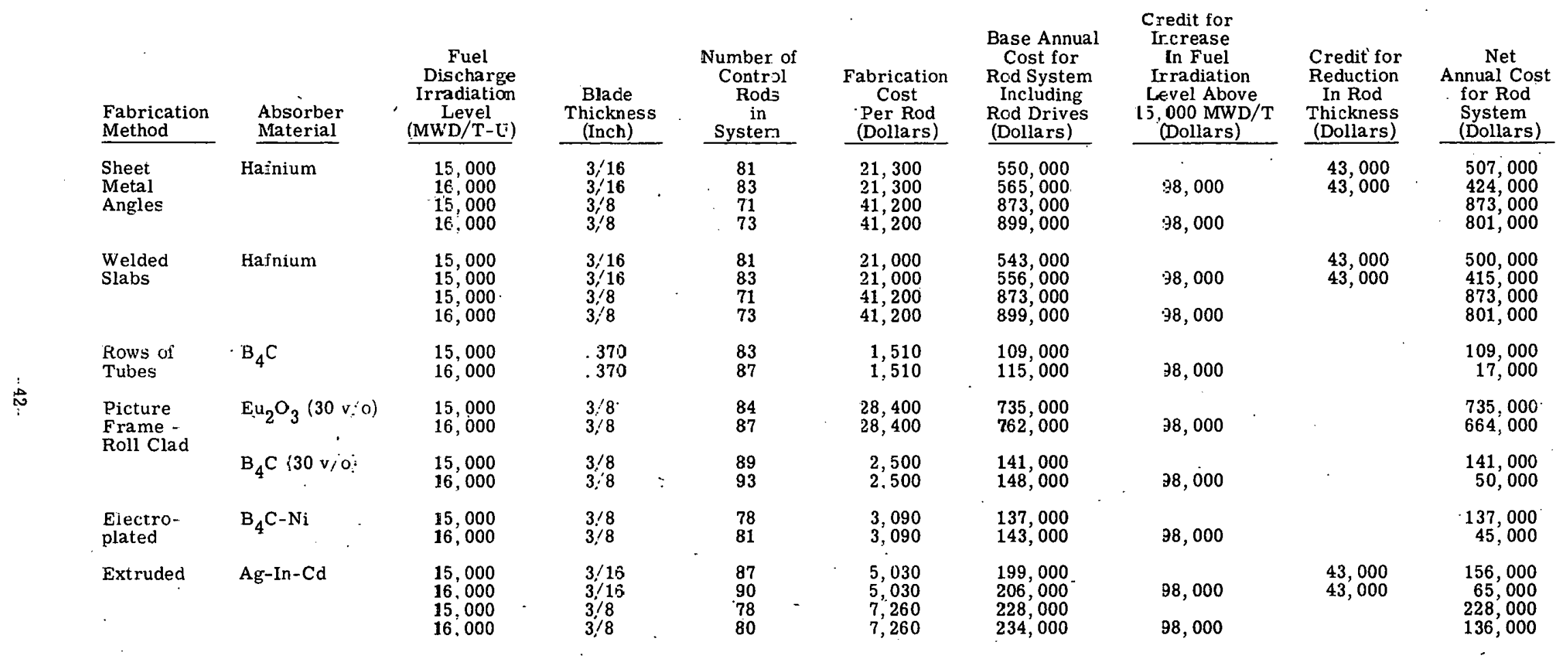


TABLE VII

ANNUAL COSTS OF FIVE-YEAR 97-ROD CONTROL SYSTEMS

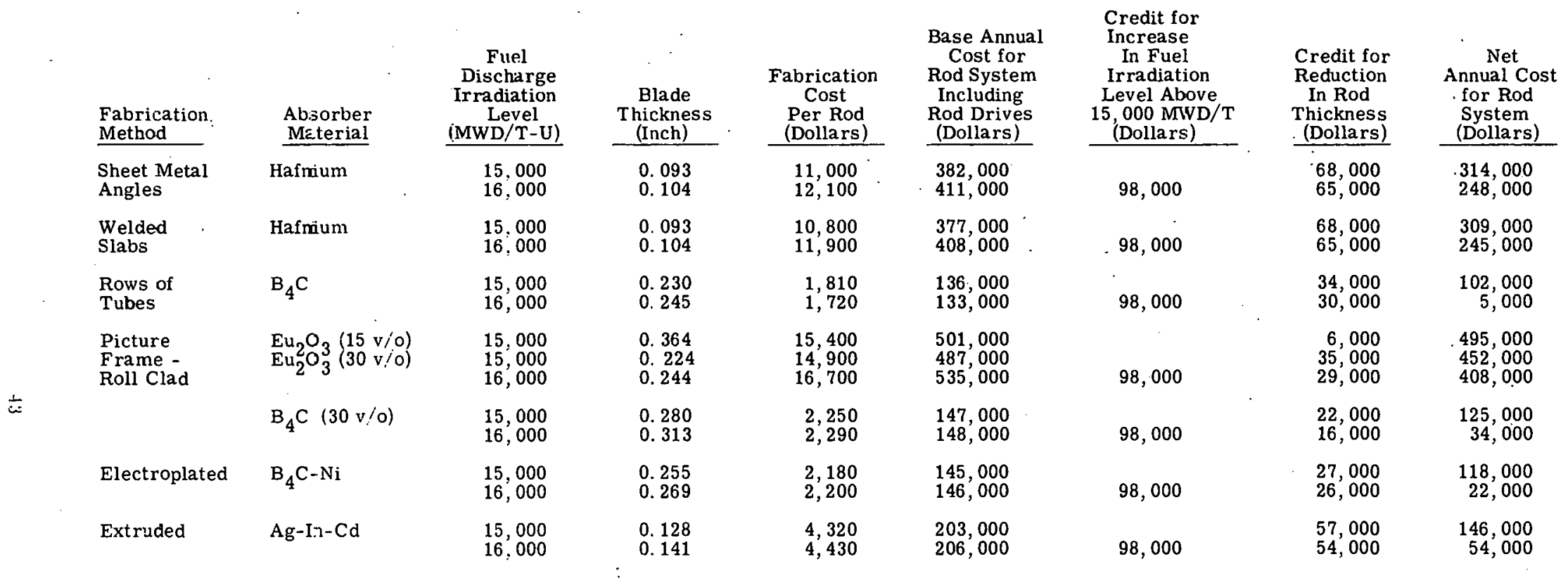




\section{REFERENCES:}

1. GEAP-3344, "A Method for the Comparative Evaluation of Reactos Control Materials", T. J. Pashos, G. D. Ritland, and J. L. Russell Jr. , April 13, 1960.

2. GEAP-3201, "Relative Effectiveness of Reactor Control Materials" R. A. Becker and J. L. Russell, Jr., July 20, 1959.

3. GEAP-4017, "Absorber Burnup Final Report", M. R. Carrothers and J. L. Russell, Jr. (to be published)

4. "Control Rod Economics", W. K. Anderson, C. J. Beck, and J. S. Theilacker. Nuclear Science and Engineering, January 1961, pp. 1-15.

5. TID-8500 (Part 1), "Boiling Water Reactor Study; $304 \mathrm{Mw}$ Power Reactor Conceptual Design", July, 1959.

6. TID-8500 (Part 1 - supplement), "Builing Water Reactor Design Study; Refinements of $304 \mathrm{Mw}$ 'Power Reactor Conceptual Design", February, 1960.

7. ANL-5607, "The Experimental Boiling Water Reactor", Argonne National Laboratory, May 1957, pp. 30-33.

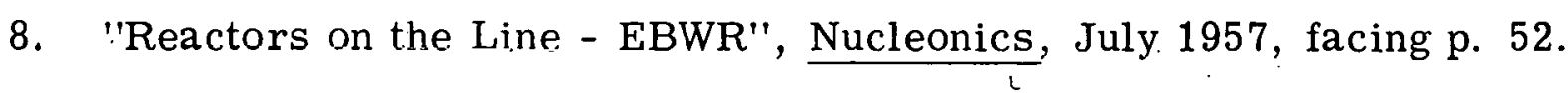

9. "Reactors on the Line - Dresden", Nucleonics, December 1959, p. 69.

10. GEAP-3842, "Hydration Resistant Compositions of Dysprosium OxideTitania"; H. E. Perrine, November 1, 1961. 
11. GEAP-3763, "Boron Carbide Control Blades for the Dresden Nuclear Power Station", J. Jacobson, C. R. Jones, and G. M. Roy, July 1, 1961.

12. ORNL-2733, "Specifications and Fabrication Procedures on EuropiumBearing Absorber Rods for Reactivity Control in Core II of SM-1", C. F. Leitten, Jr., R. J. Beaver, J. E. Cunningham, July 29, 1959.

13. "Composite Neutron-Absorbing Materials for Control Rod and Screening Applications", E. J. Bradbury, C. R. Sutton, and D. K. Worn. A/CONF. 15/P/1454, Second United Nations' International Conference on the Peaceful Use of Atomic Energy, September 1958.

14. GEAP-3831, "Investigation of $\mathrm{B}_{4} \mathrm{C}-\mathrm{Ni}$ Electro-Dispersions for Control Rod Application", H. E. Williamson, D. L. Zimmerman, and K. C. Antony, November 3, 1961.

15. GEAP-4037, "Application of $\mathrm{B}_{4} \mathrm{C}$-Nickel Electro-Dispersion to a Prototype Control Rod", H. E. Williamson and A. J. Alexander (to be published).

16. YAEC-156, "Fabrication of a Silver-Indium-Cadmium Alloy Control Rod for the Yankee Critical Experiments", J. R. Dazin, February, 1960.

17. YAEC-140,"Fabrication of a Ag-In-Cd Control Rob Absorber Section for the Yankee Reactor", E. S. Foster, August 1, 1960.

18. "Reactors on the Line -- Yankee", Nucleonics, March 1961, p. 53. 
19. GEAP-3201-2 (supplement), "Relative Effectiveness of Reactor Control Materials", Walter R. Morgan, John L. Russell, Jr., and William C. Ballowe, January 11, 1962.

20. GEAP-3764, "Determination of Lifetime of the $\mathrm{B}_{4} \mathrm{C}$-in-Tubes Control Rod", F. H. Megerth, July 19, 1961. 